\title{
Exploring English Writing Teachers' Self-development through the Use of Online Resources in Constrained Contexts
}

\section{Xiaodong Zhang}

Beijing Foreign Studies University, School of English and International Studies

\section{Abstract}

This study reports on how English writing teachers empowered themselves to connect linguistic knowledge and online resources to develop students' renewed understanding of writing beyond the structure level. The study mainly relied on qualitative analyses of a college English teacher's reflections, his verbal interactions with students, as well as his students' essays and interviews. The study shows that in the process of selfdevelopment, the teacher experienced a diverse array of challenges. Despite this, the teacher's self-development through the use of online resources was facilitated by his incorporation of linguistic knowledge, which helped his students transcend their previous writing practices, and construct culturally and linguistically effective written discourses. The study concludes that teachers' self-development to facilitate students' written communication in constrained contexts is useful, and synergizing online resources and linguistic knowledge is helpful for overcoming challenges encountered in the process of self-development.

Keywords: curriculum innovation; constrained contexts; online resources; meaningmaking; self-development; written communication

\section{Introduction}

Written communication is closely related to college students' success (Goodfellow, 2005; Taffs \& Holt, 2013). Indeed, to meet course requirements, college students need to produce various genres of writing, such as scientific reports, research papers, or even personal stories (Bibila, 2010; Dreyfus et al, 2016). To construct effective and authentic 
writing, college students have to display specific linguistic features beyond sentential accuracy, for example, discipline-specific terms, explicit logical connections, and flexible authorial stances (de Oliveira \& Lan, 2014; Schleppegrell, 2004). Unfortunately, writing instruction in many disciplines, such as science or history, is still limited to an emphasis on linguistic form, which fails to engage students effectively in discourse production (Fang, 2014). For example, college teachers in China primarily instruct how to structure writing components (e.g. introduction, body, and conclusion) while emphasizing sentential accuracy (Zhang, 2017). In addition, a lack of effective in-service or preservice training programs has also failed to support college teachers in understanding what effective written communication looks like (Zhang, 2017). Worse still are the textbooks that writing instructors primarily follow to teach writing, such as scientific reports or other academic essays. Textbooks should be a valuable resource, but their content is generally not perfect, and they do not provide effective teaching guidelines and information pertinent to students' successful written communication (Fang, 2014; Jakubiak \& Harklau, 2010; Zhang, 2017).

In response to the constraining factors mentioned above that affect effective college writing instruction, teachers' self-directed development (i.e. reliance on themselves) in optimizing available resources is useful to better prepare students for successful writing (Zhang, 2018). In particular, given that textbooks teachers rely on to develop students' writing knowledge generally include writing structure guidelines, sample writing, and unprincipled knowledge (Zhang, 2017), supplementing classroom writing instruction with other resources is suggested; for example, using online resources because of their convenience and wide availability (Kwak, 2017; Yuan \& Recker, 2015). Unfortunately, a limited number of empirical research studies thus far have highlighted how college teachers galvanize themselves in using online resources for developing written communication. To this end, this study explores how a college teacher who teaches writing harnessed his self-agency to adopt online resources and prepare students' adjustment to authentic writing. The purpose of this study is to shed light on potential areas of writing curriculum innovation in constrained educational contexts.

\section{Theoretical Framework}

\section{Online resources as a tool for writing development}

Online resources have been regarded as helpful for optimizing the existing classroom teaching scenarios (Goodfellow, 2005). Indeed, many online resources are free to users and easily accessed for multiple rounds of learning, making them valuable additions to mandatory textbooks used in the classroom (Taffs \& Holt, 2013). In addition, these resources are also characterized by their multimodal means of providing educational content, such as videos and articles, thus serving as interactive tools that grab learners' attention (Bibila, 2010). While recognizing the pedagogical importance of online resources, studies on online resources for written communication have mainly been restricted to the macro dimensions, such as how to use web-based technology to create online platforms (e.g. Wiki or Google Docs) for conducting collaborative writing and creating interactive 
environments between teachers and students or among students (e.g. Goodfellow, 2005), the use of corpora to offer lexical resources for students in different disciplines (e.g. Chang \& Kuoo, 2011), or providing e-courses on academic writing (Bibila, 2010). For instance, Taffs and Holt (2013) conducted a case study in an undergraduate environmental science classroom in Australia. Through surveys on students' experiences with academic writing, their study showed that online resources, such as podcasts, were useful for students to gain discipline-specific knowledge for environmental science writing, particularly on how to structure a literature review and create references. The authors concluded that explicit instruction of academic discourses through e-resources was beneficial. A similar concern on discourse structure was shown in Xing, Wang, and Spencer's (2008) experimental study, which found the power of e-resources to raise Chinese college students' discursive awareness, such as topic sentences, supporting sentences within a paragraph, and connections between sentences. In a more recent study, Kwak (2017) investigated Korean middle school students' exposure to online resources (e.g. video resources, e-books, and a discussion platform). Through a qualitative analysis of teachers' interviews and researchers' reflective journals, the study showed that teachers favored and followed guidelines provided by online resources. They also made modifications to their teaching styles, such as increasing teacher-student interactions and using group discussions, to better engage students in creative writing.

Obviously, while these studies highlight the use of online resources in establishing students' knowledge repertoire for written communication (e.g. Taffs \& Holt 2013), they mostly focused on using online resources to understand the structure of writing (e.g. Xing et al., 2008), enrich the content of students' writing (e.g. Kwak, 2017), or introduce sporadic lexical resources needed for writing (Bibila, 2010). However, they failed to provide principled linguistic knowledge accessible to students. In other words, regarding the pedagogical use of online resources for written communication, an important issue has been ignored; that is, how principled language resources for writing (within a sentence or between sentences) can be incorporated into the writing curriculum. In particular, in constrained contexts, teachers lack relevant knowledge or external guidance, and do not know how to develop curricula on using online resources. In response to these disadvantageous conditions, teachers' self-development (e.g. teachers' reliance on themselves) seems a potentially useful way to overcome constraints and better use online resources for writing instruction (Beach, 2017; Mushayikwa \& Lubben, 2009).

\section{Teachers' self-development}

Teachers often struggle when their pedagogical knowledge cannot effectively meet their students' needs (Beach, 2017; Mushayikwa \& Lubben, 2009; Ruan \& Recker, 2015). In these scenarios, teachers can initiate self-development, with the ultimate purpose of finding pedagogical solutions and applying them to the actual classroom (Beach, 2017; Nunan \& Lamb, 1996; Visser et al., 2014). They can conduct pertinent research and investigate classroom issues based on their current classroom situation (e.g. limited teaching guidance in the textbook or constrained knowledge they can impart to students) 
(Beach, 2017). However, self-development is not an easy journey; it is a process of actualizing the teachers themselves, encountering challenges, building confidence, and effectively engaging in teaching improvement (Nunan \& Lamb, 1996). In other words, it may involve teachers' temporary cognitive complexity, de-motivation, or students' unwillingness to participate (Mushayikwa \& Lubben, 2009). It is the emerging intrinsic reward (i.e. teachers' sense of achievement) and external reward (i.e. students' progress) that re-galvanize teachers' self-development to overcome challenges and achieve the desired curricular purpose (Louws et al., 2017).

Indeed, empirical research studies have revealed the power of teachers' self-development in improving learning contexts, including the use of online resources, although this line of research is still constrained to general learning, and not specifically to writing development. For example, in Mushayikwa and Lubben's (2009) report, they conducted a two-year study on pre-university mathematics and science teachers in Zimbabwe, and explored the use of online resources for self-directed development. Through qualitative analyses of interviews, their study illuminated that self-development closed the gap between professional support and students' needs. For example, teachers used online resources to enrich subject knowledge or adapt syllabi or teaching approaches for their students, which helped them gain confidence as teachers. Particularly in the area of writing instruction, pertinent research on self-development of teachers teaching writing is still lacking, let alone using online resources as a praxis for self-development. Among them, one research is Zhang's (2017) study, which investigated how a teacher of English as a foreign language (EFL) in China relied on himself to guide his students in understanding writing beyond individual sentences (i.e. the sentential cohesion). Through qualitative analyses of teacher interviews and classroom activities, the case study showed the role of the teacher's agency in improving the teaching of writing knowledge in a constrained context. However, the study focused on the teacher's emotional journey in this process, and did not particularly reveal the use of materials (e.g. online resources) in the classroom.

As can be seen above, self-development, along with online resources, is a useful way for teachers to overcome constrained resources. Yet, in terms of writing instruction, almost no research has been conducted thus far in this regard, let alone on how to effectively enact an online resource-based writing curriculum and guide students in constructing effective writing. In addition, given that writing is more than structural accuracy (Fang, 2014), teachers' flexible use of online resources to support students' development would be beneficial. That is, when teaching writing, teachers need a guiding lens or tool when conducting self-development, which is crucial to the success of their endeavor (Nunan \& Lamb, 1996).

\section{Systemic functional lingusitics(SFL)-based perspective on the teaching of English writing}

Among many possible tools that can assist self-development of teachers who teach writing, Halliday's (1994) systemic functional linguistics (SFL) seems quite appropriate. It highlights literacy demands beyond structural accuracy: how contextually appropriate 
linguistic choices have to be made. This is well-aligned with the expectations of valued writings in English communities (Dreyfus et al., 2016). In addition, within the framework, SFL provides more micro explanations on which linguistic features are linguistically and discursively valued in written communication (Fang, 2014).

In particular, at the macro and meso levels, SFL provides constructs of genre and register in emphasizing how written communication is a socially embedded activity (Halliday, 1994). Genre is a matrix concept that emphasizes language as a culturally regulated activity that occurs in a normalized sequence (i.e., how writing proceeds in a staged process; for example, the introduction, body, and conclusion in expository essays). Register at the meso level further explains how discursive activities interact dynamically with the context of writing being constructed. The register includes three variables. Field is about what is going on in a piece of writing. Tenor is about how writing has to interact with the audience. Mode is about the written channel of writing. Based on the three variables, written communication conveys three meanings respectively: ideational meaning, interpersonal meaning, and textual meaning. The three meanings constitute the content of the written communication.

Not limited to this, with the exception of structural accuracy, the SFL perspective also provides categories that deconstruct three dimensions of the meanings, revealing the mystery of authentic English writing at the linguistic level (Fang, 2014; Halliday, 1994; Schleppegrell, 2004). That is, for ideational meaning, codes have participants and processes, which can help reveal the features of writing (e.g. the use of non-human subjects, nominalization in scientific reports, or a diverse array of reporting verbs, ranging from claim to note to suggest when arguing for or against a position in argumentative writing). For interpersonal meaning, codes include attitude (e.g. authorial emotion, judgment), engagement (i.e. the source of information), and graduation (i.e. the intensity of semantic load), and show how lexical and grammatical resources (e.g. adjectives, adverbs, and modal verbs) unpack interpersonal meaning in different genres (e.g. implicit use of attitudinal resources, frequent use of engagement, and careful use of graduation in scientific or academic essays in order to maintain the objectivity of information). Cohesive ties as codes for textual meaning (e.g. conjunction words, lexical repetition) illustrate how valued written sentences are connected with each other, along with theme patterns (e.g. repetition in the starting point of neighboring sentences).

Indeed, a large body of research has documented the power of SFL in traditional classrooms with textbooks (e.g. Accurso et al, 2016; de Oliveira \& Lan, 2014). This line of study has been conducted more in contexts where SFL experts guided teachers or students in learning SFL. For example, Mitchel and Pessoa (2017) focused on how explicit instruction of SFL impacted students' writing performance. By specifically focusing on two college students in the Middle East, their study, through qualitative analyses of the students' interviews and writing pieces, illuminated that students could effectively construct history texts through the use of reporting verbs (e.g. imply, suggest, show) to justify or counter information or present the relationship between the overall claim 
and supporting details through thematic progression. Regarding scientific writing, Accurso et al's (2016) 12-week case study illustrated how an elementary school teacher in the United States (US) was supported by SFL experts in guiding students' scientific writing. With professional training, the teacher in the case study well facilitated students' knowledge of features of scientific writing by helping them access linguistic resources (e.g. the use of scientific words, rather than everyday language, avoiding first-person subjects, and the use of conjunction words in connecting ideas). These studies, albeit the pedagogical focus was in traditional classrooms where SFL practices were initiated or guided by external experts rather than the teachers themselves, helped students better understand the intricacy of writing and regulate their writing into valued compositions. This clearly demonstrates the power of SFL to facilitate students' writing development by paying dual attention to language form and meaning-making in context. As such, in constrained contexts, teachers' self-development through the use of online resources within this framework would be potentially helpful for effective writing instruction. Unfortunately, no such research has been conducted thus far.

In sum, based on the three lines of the literature reviewed above, it is important to synergize teachers' self-agency, online resources, and SFL-based perspective on writing in order to better prepare students for successful written communication. Unfortunately, no research has been conducted in this regard. To fill this research gap, as well as to investigate the areas of writing curriculum innovation for similar contexts where teachers' self-development is needed, this study seeks to answer the following question: how did the teacher conduct self-development in a writing classroom where the SFL-based use of online resources was adopted?

\section{Research Method}

The purpose of the study was to explore the use of online resources by those teachers who were teaching writing in constrained contexts. Therefore, a case study approach, which offers an optimal way of investigating contextually embedded activities through focusing on representative participants, was adopted for this project (Panton, 2005).

\section{Research context: Curriculum and classroom setting}

The study was carried out in the English department at a leading university in China. Writing instruction in the university was offered to the first and second-year undergraduate students. Courses included narrative, expository, argumentative, and research-based writing (i.e. students chose their own research areas and wrote research papers) in the four academic semesters of the first two academic years. The teaching of writing at the university, similar to many contexts, was focused on language accuracy (Schleppegrell, 2004; Zhang, 2017). Meanwhile, students were taught to read some materials in the mandatory textbooks that primarily included some reading materials and sporadic language knowledge (e.g. how to use modal verbs). Additionally, the departmental assistance to teachers was more about providing some general guidelines 
(e.g. the generic structure of writing), without advising teachers on how to effectively teach writing. Obviously, the institutional scenario typical of constrained contexts made the department at the university an appropriate site for a case study on how teachers improved their own teaching of writing knowledge.

Furthermore, Henry (a pseudonym) and his students in the expository and argumentative course were chosen as the focus of this case study because of their appropriateness and representativeness (Panton, 2005). In particular, Henry held a Ph.D. degree in linguistics from a US college. After his graduation, Henry returned to China and taught writing at this Chinese university, including expository and argumentative writing, although he had never taught writing at the college level. Without effective assistance and helpful textbooks, Henry had to rely on himself in this constrained context, like many other teachers (Accurso et al., 2016; Zhang, 2017). However, based on a survey and analysis of his students' writing knowledge and practices, Henry was determined to help his students engage in effective writing by using additional learning resources (i.e. SFL-based use of online resources). As such, Henry was a typical self-reliant teacher, worthy of investigation (Beach, 2017). Furthermore, all students in the expository and argumentative course were willing to participate in this study, and they felt comfortable sharing thoughts on the curriculum. Prior to their learning with Henry, the students' writing instruction included textbook-based learning and was limited to grammar, which is the case with student writers in many other contexts (e.g. Zhang, 2017; Schleppegrell, 2004), as revealed by Henry's survey. In other words, the students had never been exposed to online resources or SFL-based learning. This further justified the selection of Henry's classroom for this case study on a teacher's self-development in using online resources to develop students' knowledge of written communication.

In Henry's class, the expository writing topic was suggested by Henry and voted on by the students. It could be related to diverse topics, such as scientific topics (e.g. cause and effect of global warming) or common ones (e.g. the difference between college life and high school life). Each essay could range from 500 to 600 words. Similarly, the argumentative writing topics were also diverse, including the risks or benefits of implementing the death penalty and commercial surrogacy. The word count for each argumentative writing was approximately 1,000 - 1,500 words. During his self-development, in addition to the reading content in the mandatory textbook, Henry's teaching was primarily conducted in accordance with the SFL-based construct, while corresponding online materials were selected and used for class or assigned to students for their after-class practice (see Table 1 below; see also Zhang, 2018). The overall purpose of the self-directed curriculum was primarily concerned with using SFL-informed online resources to help students understand the knowledge related to the mystery of writing.

As shown in Table 1 above, the self-development curriculum bridged SFL-based writing knowledge, writing sample-based teaching, and online resources. During the process, Henry balanced the knowledge of theory and practical applicability through a mediating process. 
Table 1

The Core Content of Online Resource-Related Instruction in the Writing Classroom

Online resource- Selection of texts (i.e. expository and argumentative texts) published by based self- $\quad$ an authoritative website (e.g. Cengage) and further screened by language development: literacy experts.

Selection of online resources that cover meta-linguistic knowledge of $\mathrm{SFL}$. They included materials on the main constructs of SFL crucial to students' construction and deconstruction of written discourses. That is, online materials covered the knowledge of genre, register, three meaning dimensions, and key codes. Along with this, relevant practices were also selected to enhance students' understanding.

Synergizing online resources (sample texts and audio-visual resources) and teaching them through a mediated process (including helping students deconstruct sample texts and construct their own in and out of class). Meanwhile, students were also instructed to write reflections based on their learning of online resources and their ongoing writing within the frame of SFL.

\section{Data collection and analysis}

Data were mainly collected in Henry's expository and argumentative courses. In addition to Henry, all of his students $(\mathrm{N}=38)$ agreed to be involved in the study after their grades were posted, which ensured the research ethics of this study. Therefore, all of them were focused during the study. The data included Henry's written reflections (TR) over each semester of the two courses, and his discussions inside and outside of class with his students (TD). Henry's reflections were about his experiences over the two semesters while conducting self-development in his expository and argumentative course (e.g. challenges or gains in this process). For discussions related to the two courses, they mainly occurred when Henry and the students negotiated with each other on how to optimally construct writing and how to best understand texts as contextually embedded discourses. It has to be noted that the knowledge that the teacher and students drew on during discussions was provided by online resources that cover holistic and sufficient knowledge of SFL, which is also a key component of this current research study (MackenHorarik et al., 2011).

In addition, to further reveal the intricacy of Henry's journey of self-development, data collection also included students' reflections (ST) and interviews (SI) in each course. Students' reflections were primarily about their experiences with the curriculum initiated by the teacher. For example, their reflections included their interactions with the content of online resources and their learning journey in this process. Meanwhile, semi-structured interviews were also conducted in order to further elicit their response to the curriculum or to clarify their reflections over the two courses. The interview questions included how they adapted to the difficulties of the new curriculum, in addition to others that were not covered or elaborated on in their reflections. Additionally, students' assignments- 
four essays in the expository course and three essays in the argumentative course (with multiple rounds of each paper along with feedback) - were also collected. Their written documents served to further illuminate the impact of the teacher's self-development through the use of online resources in the classroom.

Data analysis was primarily informed by inductive content analysis (Creswell, 2012). In particular, in the process of data analysis, relevant data sets were first compared and condensed through constant comparisons. For instance, when analyzing the journey of Henry's reflections and verbal discussions, they were read and compared many times, before refined themes were unearthed. Preliminary codes at this stage included teacher's struggles, de/motivations, and confidence construction. To triangulate data analysis and enhance validity as well as to show an in-depth picture of this case study, other data (i.e. students' interviews, reflections, writing artifacts and field notes) also underwent similar analytical procedures, which served to further corroborate or negate the data analysis related to the teacher. It has to be noted that in the two parts of data analysis, relevant literature (e.g. Louws et al., 2017; Mushayikwa \& Lubben, 2009; Zhang, 2017) and field notes related to the two courses were also consulted, in order to facilitate theme retrieval. In the end, the themes generated from each dataset were further compared and synthesized until major findings related to the research question were gleaned.

\section{Research Findings}

Despite a difficult journey of self-development, Henry solved well his students' writing issues that were limited to accuracy at the structural level. He particularly empowered himself in drawing on online resources (including those on SFL-related knowledge and sample texts) in supporting his students' transition into writers who could harness writing-specific linguistic resources to construct effective writing. As a result, Henry constructed his confidence as being a helpful teacher by relying on himself in the face of limited institutional assistance.

\section{Initial factors that motivated Henry's self-development}

Henry's self-development was triggered by his determination to make students into authentic writers. As he reflected:

"My students did not know how to write effectively. At the beginning of the semester, I did a survey and a preliminary test; their knowledge was really limited to grammar... I do not blame them... but I really want to help them". (TR excerpt)

Echoing this, one student in the argumentative course reflected: "Whenever we learned a new type of writing, we basically ended up writing whatever came to our mind and paid attention to the structure and sentential accuracy" (SR excerpt). Apparently, Henry's self-development did not arise out of a vacuum. It was propelled by his discovery of his students' writing issues in the writing classroom, which was further motivated by his passion to benefit his students' writing development and to counteract students' previous learning experiences. Henry's self-development was particularly enhanced by 
his knowledge base of what constitutes effective writing, and propelled by his confidence that emerged out of his own positive experiences with writing learning. As he discussed with his students:

"You know... writing is not just producing grammatically correct sentences... it has a specific social purpose... and linguistic features... And I really hope you can do it accordingly... But I understand your current scenario... and I had similar writing experiences". (TD excerpt)

Similarly, he also reflected:

"I was just like them when I was in China. But I felt the power of effective guidance when I was in the US learning writing. With similar teaching... I believe my students can also make progress and do well". (TR excerpt)

The excerpts show that Henry's own experiences in China before he had studied in the US struck a chord with his students. With his refreshed understanding of effective writing as well as his positive writing experiences due to effective instruction, Henry felt motivated and confident that his students could be taught to be better writers.

Henry's determination on initiating self-development was also enhanced by his attempts to meet the students' own needs to be good writers; however, they did not know what to do. As Henry reflected:

"In discussions with students, they felt confident with their grammar yet paradoxically frustrated with writing... they said the only knowledge they have about writing is to watch for grammar... they did not have anything else to ensure the quality of their writing... I feel students' struggle with writing or composing writing this way (attending to structural accuracy) is really out of a lack of writing knowledge, so I have to help them improve themselves". (TR excerpt).

Henry's concern for students' needs was also echoed by one student's interview:

"In fact, I have not just been writing this way... I just do not know what constitutes good writing... so I do it this way... I was told that tests were graded on accuracy... But I can tell my writing is far different from sample texts... I just have no idea... I want to be that great". (SI excerpt)

Obviously, Henry did not just prepare to initiate a curriculum out of his personal preference. Instead, his decision was based on his students' needs for improved teaching (those who wanted to improve and challenge themselves but just had no relevant knowledge to rely on), which is an important component for successful self-development (Nunan \& Lamb, 1996).

\section{SFL-based use of online resources as a way of expediting self-development}

Henry's attempt at self-development was soon found constrained by the content of the mandatory textbooks that his students relied on to develop their writing since the textbooks contained no sufficient writing knowledge. This prompted Henry to use 
online resources to supplement his teaching and to prepare his students for success, as shown in Henry's reflections:

"The textbook did not have everything I wanted to use, but reading is the primary channel of students' knowledge accumulation... I began to look for ways.. . and I thought about online resources... Online resources are convenient... and students can have easy access to them given the wide use of computers and mobile phones". (TR excerpt)

Echoing Henry, the students also shared the same concern in their reflections:

"We basically learn from the textbook for the content... and some sporadic language skills, such as conjunction words... but we do not know why... the textbook does not provide everything... we may gain some reading materials... and learn some grammar and some skills". (SR excerpt)

Apparently, reading materials are the primary channel for supplying knowledge in the writing classroom (Zhang, 2017). Yet, in the classroom, Henry's determination to be a good teacher was constrained by the materials that did not cover all the content needed for students' academic writing development. Despite this, Henry took an important step in his journey of self-development and decided to resort to online resources given their wide scope of knowledge.

Not limited to the use of online resources, Henry decided to organize the online resources that followed SFL-related constructs. As Henry said in the class:

"I used online resources in ESL (English as a second language) contexts and taught reading... not here in EFL contexts, let alone for writing... but given the usefulness of SFL-related constructs... I feel they are worth a try... But I will make mediations possible in case we have some particular difficulties". (TD excerpt)

In other words, in the process of self-development, Henry did not randomly use online resources to enrich students' conceptual understanding of a topic (cf. Taffs \& Holt, 2013). Instead, based on his prior experiences, Henry boldly organized the resources according to SFL in order to enrich students' understanding of writing beyond their prior knowledge, although he had never tried this before in a college writing classroom.

\section{Challenges for Henry's SFL-based use of online resources}

However, implementing online resources appeared to be a tough process for Henry because of the students' rooted learning styles gained from their previous learning. That is, students had been exposed to textbook-based writing instruction. As the students said:

I never had this before... we did not read too many online resources... just for enriching the content of a writing topic or to check grammar... I mean, we never used them as primary learning resources like we are doing now and I believe in reading textbooks.(SI excerpt)

In other words, the students did not immediately embrace the process of using online resources, as they were used to hardcopy textbooks (Kwak, 2017). As such, the students 
did not respond well initially to their teacher's interactions in class. This was illustrated in the classroom when Henry checked the students' reading about online resources in class during the initial phase of the two courses.

Henry: Did you read these resources?

Students: Yes, we did.

Henry: So what is the definition of context? And how does it relate to our writing? [Henry was asking students questions related to the materials.]

Students: No response. [They start to check their materials on their laptops or mobile phones.]

Henry: You said you have read it; then, how come you do not know?

Students: I thought you just wanted us to skim, not do a deep reading... we never had this before... reading theory in a writing classroom. (TD excerpt)

This excerpt showed that the students did not react well to the content of online resources, dismissing them as ancillary resources, which was apparently due to their previous learning habits in the traditional classroom where textbooks were used.

The students' unsatisfactory reaction bothered Henry, so he decided to improve this. As he reflected: "I think I need to have them write reflection journals, so they can really read it carefully and take the resources seriously" (TR excerpt). In other words, faced with the students' failure to embrace the new mode of using materials, Henry felt emotionally frustrated. However, he did not give up but constantly empowered himself to think of ways to solve the issues emerging on his journey of self-development.

In addition, Henry's challenge also arose out of his negligence to recognize the students' difficulties with understanding and applying the meta-linguistic knowledge to their writing or generic demands. As one student reflected:

"I find it a bit difficult to understand the content... a lot of linguistic terms need to be digested... and I feel overwhelmed. Also, somehow I understand what the content says or the teacher says, for example, how to use reporting verbs, but I could not do it myself... and found myself ending up still writing this way". (SR excerpt)

Indeed, the process of writing progressed much slower than their gains from their reading (Stotsky, 1983). That is, although the students could understand the content of the online resources, they could not apply it to their writing.

Henry's self-development was further hindered by the students' difficulties with digesting linguistic demands beyond their prior knowledge (i.e. structural accuracy), especially regarding their understanding of genre-specific features, such as the inappropriate use of personal opinions in expository writing, lacking knowledge in effectively rebutting opponents' argument in argumentative writing, and failing to show cohesion or logical connectors in both types of writing. That is, these students did not adequately internalize the knowledge from these online resources. In other words, challenges in this regard 
were related to Henry's failure to attend to the students' conceptual workload. As such Henry reflected: "I have to think of a way to help them... nothing can be easy."(TR excerpt)

To solve the issues among his students, Henry readapted the online resources by reducing the reading load and highlighting core tenets (Macken-Horarik et al., 2011), while providing a diverse array of mediation inside and outside of classroom tutoring (e.g. many rounds of feedback based on the needs of each student; field notes). He decided to re-teach the materials, based on good-enough principles gained from his consultation of references (field notes). This seemed to change the scenarios. As one student from the expository course reflected: "Through this back and forth negotiation, such as written feedback and discussions in and out of class, I can now better understand the value of online resources and their connection to writing." (SI excerpt)

Similarly, another student from the argumentative course also reflected:

"I feel the reading load is more scientifically organized... and the teacher also gave us more practice in class and also offered extra assistance out of class... this helped me better adapt to the curriculum". (SI excerpt)

Obviously, the challenges emerging on the road of Henry's self-development were sporadic. In response to this, Henry was constantly empowering himself to look for solutions to help the students emancipate themselves from their previous learning styles, which was bolstered by the confidence that Henry continuously gained in this process. As he reflected: "I did not feel successful all the time... but I do feel the students' progress, although not in the smooth way I had expected... they made slow progress, still they are growing... This helped me to continue implementing my curriculum plan in my classroom while motivating me to look for strategies to better help students adjust to the curriculum I initiated.' (TR excerpt)

\section{Henry's re-conceptualization of the teacher's role and the construction of his confidence to adopt SFL-based online resources as a result of his students' progress}

At the mid-point of each course, Henry became confident because of his students' stable progress in overcoming their previous learning constraints, and with minimal mediation (i.e. teacher feedback) regulating their writing by controlling genre-specific resources. Indeed, starting from the second round of their second paper in the expository class and the second round of their first paper in the argumentative class, the students seemed to more actively respond to written feedback beforehand, such as their use of conjunction words, making transitions in their introductions, and maneuvering evaluative attitudes in their writing (see Table 3 below). In other words, unlike passive modifications of their essays early on, they started to show traces of actively revising their writing based on written feedback, as a result of their increased knowledge. 
Table 2

Students'Independent Regulation of Their Writing

Ideational meaning students could use appropriate reporting verbs when making
claims in relation to the evidence available. For example, in her
argumentative paper, one student used suggest when she found that
evidence she could provide was not compelling enough.
The students made revisions in terms of the logical relationship
between claims and evidence. For example, when revisiting her early
writing on the effects of global warming, one student highlighted the
logical connectors (e.g., because, as a result), explicitly showing the
causal relationship between statements.

Interpersonal meaning The students could appropriately show the reliability of information delivered. For example, in expository writing, one student used a quantifier most to adjust her early writing and wrote: Most Chinese high school students get up at 6 a.m.

The students could also effectively interact with readers, using different engagement resources. For example, in one student's argumentative writing, she could put up clear road signs, showing the boundary between her own and others' position. In doing so, she first used opponents of this claim... Having listed the opponents' empirical evidence for their claim, she used Nevertheless, pointing out the issues in opponents' argument and showing her position.

Textual meaning The students could also use cohesive devices. For example, in her expository writing, one student revised her early writing, using synonyms as lexical cohesion to connect neighboring sentences (e.g. global warming, high temperature on Earth). In argumentative writing, students became able to use cohesive devices to connect research evidence when showing their arguments (e.g. similarly, furthermore).

In other words, Henry's self-development prepared the students well for their transition into authentic writers beyond sentential accuracy, meeting the demands of authentic writing because of an integrated use of online resources and SFL-based guidelines. Indeed, as one student noted:

"Despite a difficult learning process, I felt confident in moving on because of the students' gradual process... the knowledge of register, and their maneuvering of three meta-meanings and relevant linguistics resources... these were definitely an additional asset to my knowledge repertoire... It enhanced my understanding of a genre-based perspective on argumentative or expository writing..." (SI excerpt)

Henry's confidence was also accompanied by his refreshed understanding of using online resource-based knowledge in bridging students' prior learning and authentic demands of writing. As Henry reflected:

"The students now do not just attend to grammar anymore; they have gained a global perspective on writing as a contextually embedded activity... everything pays off now... This has made me further believe that being a good teacher can be realized 
through our own agency... This has also made me feel more motivated in making a similar journey when I teach other courses". (TR excerpt)

"A teacher should not just rely on external resources... what a teacher does is to optimize the resources available and help students... In addition, they have to be well prepared for the challenges on the journey". (TR excerpt)

Henry, through this challenging journey during expository and argumentative writing instruction, gained a new understanding about being a professional teacher, where being a self-reliant teacher was important in a constrained teaching context in order to meet students' needs. In other words, Henry achieved a holistic perspective on being a professional writing teacher through the dynamic experiences over the two courses where he had limited institutional assistance (regarding textbook use or professional development).

Henry's re-conceptualization of the teacher's role seemed particularly evident in the confidence he displayed when the students gained a better understanding of writing at the three dimensions through the use of SFL-based online resources and meeting generic demands. As he reflected:

"It [self-development] depends on what specific tools we have to use for selfdevelopment... we cannot be blind... and we have to think about local school needs and make adaptations... the SFL seems very helpful in this process... and its usefulness could be magnified with the abundant online resources". (TR excerpt)

His confidence in the use of SFL-based online resources was particularly grounded on the following dimensions:

"Apprenticing students to read an ideational construct through online resources can offer students the choice of appropriate words and careful regulation of logical relationships...such as the appropriate use of verbs to show a different semantic load... all these are not just any grammatically acceptable ones but are sifted in a particular text type". (TR excerpt)

"The interpersonal construct and relevant online resources taught students to avoid explicit attitudinal words in supporting details... and we could bring in signals of the information source to show the reliability of text content. And we have to make changes in different genres... an argumentative claim can have an explicit attitude. No knowledge is fixed". (TR excerpt)

"Cementing textual meaning and online resources helped students who had focused more on the syntactic accuracy of sentences, without knowing cohesion... cohesive ties help me check the flow of students' writing, when they list research evidence, or in any other places of writing". (TR excerpt)

Apparently, the use of SFL-based online resources facilitated students' progress in effective written communication. The progress then fed into Henry's confidence in being a self-reliant professor who focused on the micro-level teaching of writing by drawing on online resources. 


\section{Discussion and Implications}

This case study has yielded the following findings. First of all, by focusing on Henry' selfdevelopment, especially his process of innovating his curriculum, the study illuminated the dynamic process of Henry's use of online resources to enhance his own expertise and facilitate his students' writing development. That is, through this process, Henry overcame a diverse array of contextual factors that caused his emotional upheaval. For instance, his efforts on his journey of self-development were met with such obstacles as the students' slow understanding of the new curriculum, or his negligence to recognize the students' own learning contexts in the classroom (for example, where their learning was constrained by their cognitive load). Nevertheless, Henry's rough self-development was in the end diluted because of his constant efforts to clarify the connection between the online resources, the textbook, and written communication, and to facilitate his students' understanding. As a result, his students could write for particular generic purposes instead of merely constructing grammatical sentences, which also helped construct Henry's confidence in being a self-reliant teacher in constrained contexts. In this regard, this study further complements the usefulness of self-development in constrained contexts, and particularly highlights the power of self-development in writing classrooms where external assistance is limited and teachers have to rely on themselves to teach effectively and prepare students for writing development (e.g. Mushayikwa \& Lubben, 2009; Nunan \& Lamb, 1996). In addition, this study also joins a few existing studies (e.g. Mushayikwa \& Lubben, 2009) that particularly highlight the use of online resources in teachers' self-development(cf. Louws et al., 2017). In this regard, this finding further complements previous research that focused on self-development in the traditional mode, such as teachers' selection of additional textbooks (cf. Zhang, 2017). Most importantly, by focusing on the process of Henry's self-development, the study also further empirically demonstrates the dynamics, difficulties and gains associated with technology-based self-development, which did not seem to be captured well in relevant literature (e.g. Mushayikwa \& Lubben, 2009). This sheds light on future curriculum innovation where teachers have to rely on themselves to facilitate students' learning based on online resources.

Secondly, by focusing on SFL as a praxis for teachers' self-development, this study was also able to show students' actual writing development at the linguistic level. That is, in the process, with an explicit use of SFL-based online resources in the writing classroom, the study revealed students' knowledge affordance to change their original conceptualization of writing and effectively construct writing, although this process was not smooth. For instance, despite a troublesome learning trajectory, the students were able to appropriate the SFL-related knowledge and construct professionally written texts beyond the grammatical level through exposure to Henry's self-development-based curriculum. In this regard, the study complements the traditional line of research where teachers were guided by experts in using SFL, which supported their students' writing literacy development (cf. Accurso et al., 2016; Mitchell \& Pessoa, 2017; de Oliveira \& Lan, 
2014). However, by demonstrating the teacher's self-agency in using SFL as a tool and connecting with online resources, this study further complements the existing literature on writing pedagogy by highlighting SFL as an effective tool for using online resources as teaching and learning materials. In other words, this study also adds to the repertoire of tools for self-development of teachers teaching writing in constrained contexts, and better answers the call by Taffs and Holt (2013) that "educational design decisions about e-resource development must focus first on the purpose and pedagogy, rather than just the technologies available." (p. 500)

The implications of this study include the following folds. First, while self-development is crucial to teachers' professional development and students' academic success, teachers and students may both experience emotional ups and downs in this process. This means that even in constrained contexts where external support cannot be provided in an official or principled manner, collegial collaborations (e.g. experts on linguistics or online technology) should be undertaken in order to help teachers adapt to the journey of selfdevelopment and become less anxious in the process. In addition, self-development could also be constrained by teachers' negligence of students' needs. In other words, inservice teacher education programs should train teachers as reflective professionals so that they can effectively participate in self-development during their own careers. Most importantly, given that written communication involves a complex system and SFL is convenient for explaining written discourse, prompting SFL-based in-service education among language educators seems useful for facilitating their future self-development and preparing students for successful written communication.

\section{Conclusion}

Through a case study, the project has two important findings that shed light on online resource-based curricula for teaching written communication. Firstly, the study shows that in a constrained context, teachers' self-development is crucial for optimizing their instruction of written communication. Without relying on external support, teachers could galvanize their own agency to discover their students' writing issues related to their writing process, find solutions, and through trial and error, improve students' skills in conducting written communication. More importantly, the study also shows that the synergy between SFL and online resources seems useful for expediting the process of teachers' self-development and enhancing students' written communication. With the multi-layer constructs and an emphasis on authentic communication, this foundation is useful to guide teachers in finding solutions to their students' writing dilemmas, where they are inclined to focus on sentential accuracy rather than negotiating authentic discourse.

The limitations of this study cannot be ignored. Indeed, as a case study, the findings have to be treated cautiously. In addition, other factors might also need to be considered when promoting self-directed development, such as whether teachers are allowed to design their own curriculum. In addition, the teacher in this study had some background 
in linguistics, which to some extent may have helped him conduct self-development. Future studies could focus on teachers who have no linguistic background and investigate their online resource-based self-development and professional identity construction.

\section{Acknowledgment}

The project is funded by National Social Science Foundation of China (17CYY019).

\section{References}

Accurso, K., Gebhard, M., \& Selden, C. (2016). Supporting L2 elementary science writing with SFL in an age of school reform. In L. C. de Oliveira, \& T. Silva (Eds.), Second language writing in elementary classrooms: Instructional issues, content-area writing and teacher education (pp. 126-150). New York: Palgrave Macmillan.

Beach, P. (2017). Self-directed online learning: A theoretical model for understanding elementary teachers' online learning experiences. Teaching and Teacher Education, 61, 60-72. https:// doi.org/10.1016/j.tate.2016.10.007

Bibila, S. (2010). Piloting a vocational e-course at a UK college: Developing strategies to support non-native English speaking learners to complete the essay-type questions of their assignments. Turkish Online Journal of Distance Education, 11(2), 23-39.

Chang, C. F., \& Kuo, C. H. (2011). A corpus-based approach to online materials development for writing research articles. English for Specific Purposes, 30(3), 222-234. https://doi. org/10.1016/j.esp.2011.04.001

Creswell, J.W. (2012). Qualitative inquiry and research design: Choosing among five approaches. Thousand Oaks, CA: Sage.

de Oliveira, L. C., \& Lan, S. W. (2014). Writing science in an upper elementary classroom: A genre-based approach to teaching English language learners. Journal of Second Language Writing, 25(1), 23-39. https://doi.org/10.1016/j.jslw.2014.05.001

Dreyfus, S., Humphrey, S., Mahboob, A., \& Martin, J. M. (2016). Genre pedagogy in higher education. The SLATE project. London: Palgrave Macmillan. https://doi.org/10.1007/978$\underline{1-137-31000-2}$

Fang, Z. (2014). Preparing content area teachers for disciplinary literacy instruction. Journal of Adolescent \& Adult Literacy, 57(6), 444-448. https://doi.org/10.1002/jaal.269

Goodfellow, R. (2005). Academic literacies and e-learning: A critical approach to writing in the online university. International Journal of Educational Research, 43(7-8), 481 494. https:// doi.org/10.1016/j.ijer.2006.07.005

Halliday. M. A. K. (1994). An introduction to functional grammar. London: Edward Arnold.

Jakubiak, C., \& Harklau, L. (2010). Designing materials for community-based adult ESL programs. In N. Harwood (Ed.), English language teaching materials: Theory \& practice (pp. 395-418). Cambridge, UK: Cambridge University Press.

Kwak, S. (2017). How Korean language arts teachers adopt and adapt open educational resources: A study of teachers' and students' perspectives. The International Review of Research in Open and Distributed Learning, 18(4), 193-211. https://doi.org/10.19173/irrodl.v18i4.2977 
Louws, M. L., Meirink, J. A., van Veen, K., \& van Driel, J. H. (2017). Teachers' self-directed learning and teaching experience: What, how, and why teachers want to learn. Teaching and Teacher Education, 66, 171-183. https://doi.org/10.1016/j.tate.2017.04.004

Macken-Horarik, M., Love, K., \& Unsworth, L. (2011). A grammatics 'good enough' for school English in the 21st century: Four challenges in realizing the potential. Australian Journal of Language and Literacy, 34(1), 9-23.

Mitchell, T. D., \& Pessoa, S. (2017). Scaffolding the writing development of the Argument genre in history: The case of two novice writers. Journal of English for Academic Purposes, 30, 2637. https://doi.org/10.1016/j.jeap.2017.10.002

Mushayikwa, E., \& Lubben, F. (2009). Self-directed professional development - Hope for teachers working in deprived environments? Teaching and Teacher Education, 25, 375-382. https:// doi.org/10.1016/j.tate.2008.12.003

Nunan, D., \& Lamb, C. (1996). The self-directed teacher: Managing the learning process. Cambridge: Cambridge University Press.

Patton, M. (2005). Qualitative research. New York: John Wiley \& Sons.

Schleppegrell, M. J. (2004). The language of schooling: A functional linguistics perspective.New York: Routledge. https://doi.org/10.4324/9781410610317

Stotsky S. (1983). Research on reading/writing relationships: A synthesis and suggested directions. Language Arts, 60(5), 627-642.

Taffs, K. H., \& Holt, J. I. (2013). Investigating student use and value of e-learning resources to develop academic writing within the discipline of environmental science. Journal of Geography in Higher Education, 37(4), 500-514. https://doi.org/10.1080/03098265.2013.801012

Visser, R. D., Evering, L. C., \& Barrett, D. E. (2014). Twitter for teachers: The implications of Twitter as a self-directed professional development tool for K-12 teachers. Journal of Research on Technology in Education, 46(4), 396-413. https://doi.org/10.1080/15391523.2014.925694

Xing, M., Wang, J., \& Spencer, K. (2008). Raising students' awareness of cross-cultural contrastive rhetoric via an e-learning course. Language Learning \& Technology, 12(2), 71-93.

Yuan, M., \& Recker, M. (2015). Not all rubrics are equal: A review of rubrics for evaluating the quality of open educational resources. International Review of Research in Open and Distributed Learning, 16(5), 16-38. https://doi.org/10.19173/irrodl.v16i5.2389

Zhang, X. (2017). Understanding Chinese EFL teachers' beliefs and practices in the textbookbased classroom. Bern: Peter Lang. https://doi.org/10.3726/b11563

Zhang, X. (2018). Connecting OER with mandatory textbooks in an EFL classroom: A language theory-based material adoption. International Review of Research in Open and Distributed Learning, 19(2),89-110. https://doi.org/10.19173/irrodl.v19i2.3479

\author{
Xiaodong Zhang \\ School of English and International Studies, \\ 19 North Xisanhuan Avenue, Beijing, China \\ zxdman588@gmail.com
}




\section{Analiza samorazvoja nastavnika koji poučavaju vještinu pisanja na engleskome jeziku kroz primjenu online izvora u ograničenome kontekstu}

\section{Sažetak}

Ova studija pokazuje kako su nastavnici koji poučavaju vještinu pisanja na engleskome jeziku sami sebe educirali i spojili jezično znanje i online izvore kako bi kod studenata produbili razumijevanje pisanoga teksta izvan njegove osnovne strukturne razine. Studija se uglavnom oslanjala na kvalitativne analize refleksije sveučilišnoga nastavnika engleskog jezika, na njegovu interakciju sa studentima te na eseje studenata i intervjue s njima. Studija je pokazala da se u procesu samorazvoja nastavnik suočio s raznovrsnim izazovima. Usprkos tome, nastavnikov samorazvoj kroz primjenu online izvora bio je potpomognut njegovom integracijom jezičnoga znanja, što je u konačnici pomoglo studentima prevladati dotadašnji način pisanja $i$ kreirati kulturno i jezično adekvatan pisani diskurs. Zaključak je studije da je nastavnikov samorazvoj koristan za razvoj vještine pisane komunikacije studenata u ograničenom kontekstu te da je sinergija online izvora i jezičnoga znanja važna u prevladavanju izazova s kojima se nastavnik suočava u procesu samorazvoja.

Ključne riječi: inovacija kurikula, ograničeni kontekst, online izvori, stvaranje značenja, samorazvoj, pisana komunikacija

\section{Uvod}

Pisana komunikacija usko je povezana s uspjehom studenata (Goodfellow, 2005; Taffs i Holt, 2013). Uistinu, kako bi zadovoljili uvjete pojedinih kolegija, studenti trebaju pisati različite vrste tekstova, poput znanstvenih izvješća, istraživačkih radova ili osobnih priča (Bibila, 2010; Dreyfus, Humphrey, Mahboob i Martin, 2016). Kako bi napisali dobre i autentične školske tekstove, studenti moraju pokazati određena jezična znanja koja nadilaze razinu rečenične točnosti; na primjer, termine specifične za određenu disciplinu, eksplicitne logičke veze te fleksibilan stav autora (de Oliveira i Lan, 2014; Schleppegrell, 2004). Nažalost, nastava u područjima različitih disciplina u sklopu kojih se poučava vještina pisanja još uvijek je ograničena na lingvističku formu, što ne pomaže učinkovitom uključivanju studenata u akademski način pisanja (Fang, 2014). Na primjer, sveučilišni 
nastavnici primarno poučavaju studente strukturiranju pisanih tekstova (npr. uvod, glavni dio i zaključak), a veliki se naglasak stavlja na rečeničnu točnost (Zhang, 2017). Uz to, zbog nedostatka učinkovitih oblika stručnoga usavršavanja za nastavnike koji već rade u nastavi i za one koji će se tek započeti takvu karijeru, nastavnici nemaju dovoljno znanja o tome kako bi dobar pisani tekst trebao izgledati (Zhang, 2017). Još je lošija situacija s udžbenicima kojih se uglavnom pridržavaju nastavnici koji poučavaju pisanju unutar različitih disciplina (znanstveni radovi i akademski eseji). Udžbenici bi trebali biti vrijedan izvor, no njihov sadržaj uglavnom nije učinkovit i ne daju nastavnicima upute i informacije bitne za uspješnu pisanu komunikaciju studenata (Fang, 2014; Jakubiak i Harklau, 2010; Zhang, 2017).

Kao odgovor na ograničavajuće faktore koji su u tekstu već spomenuti, a koji utječu na uspješnu nastavu u kojoj se poučava o vještini pisanja na fakultetu, od velike je važnosti samousmjeren razvoj nastavnika (oslanjanje na samoga sebe) prema najboljem mogućem korištenju dostupnih izvora kako bi se studente što bolje pripremilo za uspješno pisanje na akademskoj razini. Treba naglasiti, s obzirom na to da je čitanje još uvijek primaran način stjecanja znanja u nastavi pisanja, da su udžbenici nedovoljni jer sadrže samo upute o strukturi pisanoga teksta, primjere pisanih tekstova te teorijska znanja (Zhang, 2017), stoga je neophodno udžbenike dopuniti dodatnim izvorima - npr. online izvorima jer su praktični i dostupni svima (Kwak, 2017; Yuan i Recker, 2015). Nažalost, samo je mali broj empirijskih istraživanja pokazao da sveučilišni nastavnici postaju svjesni važnosti korištenja online izvora za razvoj vještine pisanja kod studenata. Zbog toga je cilj ove studije ispitati kako je fakultetski nastavnik koji poučava o vještini pisanja samoinicijativno i samostalno prilagodio online izvore i pomogao studentima prilagoditi svoj stil pisanja autentičnome akademskom pisanju. Svrha je ove studije skrenuti pažnju na potencijalna inovativna područja u kurikulu pisanja u ograničenom obrazovnom kontekstu.

\section{Teorijski okvir}

\section{Online izvori kao alat za razvijanje vještine pisanja}

Online izvori smatraju se korisnima za poboljšanje postojećih nastavnih scenarija (Goodfellow, 2005). Uistinu, mnogi online izvori mogu se besplatno koristiti, lako im se može pristupiti i mogu se višestruko koristiti, što ih čini vrijednim dodatnim materijalima uz obvezne udžbenike koji se u nastavi moraju koristiti (Taffs \& Holt, 2013). Osim toga, ovakvi izvori također imaju i multimodalne načine pružanja obrazovnih sadržaja, kao što su videomaterijali i članci. Tako mogu poslužiti kao interaktivni alati koji privlače pažnju učenika (Bibila, 2010). Iako ne osporavaju pedagošku važnost online izvora, istraživanja o njihovoj primjeni u akademskoj komunikaciji uglavnom su bila ograničena na makrodimenzije, poput toga kako koristiti mrežne tehnologije za kreiranje online platformi (npr. Wiki ili Google Docs) za suradničko pisanje, za kreiranje interaktivnoga okruženja za nastavnike i studente ili samo za studente (npr. Goodfellow, 2005), za korištenje korpusa kako bi se studentima pružili leksički izvori u različitim disciplinama (npr. Chang i Kuoo, 2011) ili za provedbu e-tečajeva o akademskome pisanju (Bibila, 2010). 
Primjerice, Taffs i Holt (2013) u Australiji proveli su istraživanje na dodiplomskom studiju ekologije. Kroz ankete o iskustvima studenata o akademskom pisanju pokazalo se da su online izvori, poput podcasta, studentima korisni za stjecanje znanja iz određene discipline, a koje im je potrebno za pisanje radova o ekologiji, pogotovo kada se radi o strukturiranju pregleda literature i izradi referenci. Autori su zaključili da je eksplicitna nastava o akademskom diskursu kroz online izvore jako korisna. Sličan interes za strukturu diskursa pokazan je u eksperimentalnom istraživanju koje su proveli Xing, Wang i Spencer (2008). Pokazalo se da su online izvori jako korisni kada se radi o podizanju razine svijesti kineskih studenata o diskursu koji uključuje tematske rečenice, razradu argumenata unutar odlomka te vezna sredstva između rečenica. U novijem je istraživanju Kwak (2017) ispitivao u kojoj su mjeri korejski osnovnoškolci izloženi online izvorima (videomaterijalima, e-knjigama i platformama za diskusije). Kvalitativnom analizom intervjua s nastavnicima i dnevnika u kojima su nastavnici bilježili svoje refleksije, istraživanje je pokazalo da su se nastavnicima svidjeli online izvori i da su slijedili upute dane u njima. Također su modificirali svoj stil poučavanja tako što su povećali interakciju između nastavnika i studenata, koristili grupne diskusije te učinkovitije uključivali studente u kreativno pisanje.

Ipak, dok istraživanja naglašavaju dobrobit korištenja online izvora za veće znanje studenata o različitim vrstama akademske komunikacije (Taffs i Holt 2013), ona su uglavnom fokusirana na korištenje online izvora za razumijevanje strukture pisanoga teksta (Xing i sur., 2008), obogaćivanje sadržaja pisanih radova studenata (Kwak, 2017) ili na uvođenje sporadičnih leksičkih izvora potrebnih za pisanje (Bibila, 2010). Međutim, online izvori nisu uspjeli dati studentima relevantno jezično znanje. Drugim riječima, što se tiče pedagoške upotrebe online izvora pri razvoju vještine pisanja, zanemarena je jedna važna stvar - kako se relevantni akademski jezični izvori (unutar rečenice ili između rečenica) mogu integrirati u kurikul pisanja. Točnije, u ograničenom kontekstu, nastavnici nemaju adekvatno znanje ni vanjske smjernice od strane stručne službe te ne znaju kako osmisliti kurikule pomoću online izvora. Kao odgovor na ove nepovoljne uvjete, samorazvoj nastavnika (npr. oslanjanje nastavnika na vlastite sposobnosti) čini se učinkovitim načinom za prevladavanje ograničenja i za učinkovitiju upotrebu online izvora u nastavi u kojoj se poučava o vještini pisanja (Beach, 2017; Mushayikwa i Lubben, 2009).

\section{Samorazvoj nastavnika}

Nastavnici su u vrlo teškoj situaciji kada njihovo pedagoško znanje ne može uspješno zadovoljiti potrebe studenata (Beach, 2017; Mushayikwa i Lubben, 2009; Ruan i Recker, 2015). U takvim okolnostima nastavnici mogu započeti samorazvoj s krajnjim ciljem pronalaženja odgovarajućih pedagoških rješenja i njihove primjene u nastavi (Beach, 2017; Nunan i Lamb, 1996; Visser, Evering, i Barrett, 2014). Mogu provoditi relevantna istraživanja i ispitati probleme koji se pojavljuju u nastavi na temelju vlastitih situacija u razredu (npr. nedostatak smjernica za nastavnike u udžbenicima ili nedovoljno široko 
znanje koje bi mogli prenijeti studentima) (Beach, 2017). Međutim, samorazvoj nije lagano putovanje; to je proces aktualizacije samih nastavnika, suočavanje s izazovima, izgradnja samopouzdanja te aktivno sudjelovanje u poboljšanju nastavnoga procesa (Nunan i Lamb, 1996). Drugim riječima, on može izazvati privremenu kognitivnu preokupiranost nastavnika i demotivaciju ili jednostavno studente ne potaknuti na sudjelovanje u radu (Mushayikwa i Lubben, 2009). Radi se o unutarnjem nagrađivanju (tj. njegovom osjećaju postignuća) i vanjskom nagrađivanju (napretku studenata) koji potiče nastavnike na daljnji samorazvoj pri prevladavanju prepreka i izazova i na postizanje određenih ciljeva zacrtanih kurikulom (Louws, Meirink, van Veen, i van Driel, 2017).

Uistinu, empirijska su istraživanja pokazala koliku moć imaju samorazvoj nastavnika i online izvori u poboljšanju obrazovnoga konteksta, iako se takva vrsta istraživanja još uvijek ograničava na učenje općenito, a ne specifično na razvoj vještine akademskoga pisanja. Na primjer, izvješće Mushayikwe i Lubbena (2009) opisuje njihovo dvogodišnje istraživanje provedeno na preddiplomskom studiju za nastavnike matematike i prirodoslovnih znanosti u Zimbabveu. U njemu se ispituje upotreba online izvora za samoinicijativni profesionalni razvoj nastavnika. Kvalitativnom analizom intervjua istraživanje je pokazalo da samorazvoj premošćuje jaz između profesionalne podrške i potreba studenata. Na primjer, oni su koristili online izvore kako bi obogatili znanje iz područja pojedinoga predmeta ili kako bi prilagodili nastavne programe i nastavni pristup svojim studentima. To je nastavnicima pomoglo steći samopouzdanje. Kada se radi o nastavi u kojoj se poučava o vještini pisanja, odgovarajuća istraživanja o samorazvoju nastavnika koji studente poučavaju toj vještini još uvijek nisu dostatna, pogotovo kada se radi o korištenju online izvora kao stalne prakse u samorazvoju nastavnika. Među tim malobrojnim istraživanjima marginalizirano je istraživanje koje je proveo Zhang (2017), a u kojemu je ispitao kako se nastavnik Engleskoga jezika kao stranoga jezika u Kini oslonio sam na sebe i pomogao studentima shvatiti kako se vještina pisanja razvija izvan granica pojedinačnih rečenica (tj. rečenične kohezije). Kvalitativnim analizama intervjua s nastavnikom i aktivnosti provedenih na nastavi, istraživanje je pokazalo koliko je važna uloga i aktivnost samoga nastavnika u poučavanju o vještini pisanja u ograničenom kontekstu. Međutim, istraživanje se fokusiralo na nastavnikovo emocionalno putovanje u tom procesu te nije posebno prikazalo korištenje različitih materijala (npr. online izvora) u nastavi.

Kako se može vidjeti iz ranije navedenoga, samorazvoj je, uz primjenu online izvora, uspješan način na koji nastavnici mogu prevladati problem ograničenih izvora. Ipak, gotovo nijedno istraživanje nije provedeno o nastavi pisanja, a pogotovo o tome kako učinkovito provesti kurikul nastave pisanja koji se temelji na online izvorima i kako naučiti studente napisati dobar tekst. Ipak, s obzirom na to da je pisanje ujedno i proces u kojemu se konstruira značenje, bilo bi jako dobro kada bi nastavnici mogli fleksibilno koristiti online izvore kako bi pomogli studentima razviti vještinu pisanja. Dakle, kada poučavaju o vještini pisanja, nastavnici bi trebali imati neke smjernice ili alate za samorazvoj, što je od ključne važnosti za uspješan rad u ovome području (Nunan i Lamb, 1996). 


\section{Online poučavanje pisanja na engleskom jeziku sa stajališta sistemske funkcionalne lingvistike (SFL)}

Među mnogobrojnima alatima koji mogu biti od pomoći u samorazvoju nastavnika koji poučavaju o vještini pisanja, Hallidayova (1994) sistemska funkcionalna lingvistika čini se potpuno adekvatnom. Ona stavlja pismenost ispred strukturne točnosti i ističe kako se prvo moraju odabrati lingvističke sastavnice koje odgovaraju kontekstu. To je potpuno u skladu s očekivanjima koja su prisutna u cijenjenim pisanim radovima unutar engleskih zajednica (Dreyfus i sur., 2016). Osim toga, a u sklopu zadanoga okvira, sistemska funkcionalna lingvistika također pruža mikroobjašnjenja o tome koje se lingvističke karakteristike u pisanoj komunikaciji jezično cijene i koje odgovaraju diskursu (Fang, 2014).

Na makro i mezorazini, sistemska funkcionalna lingvistika pruža konstrukte vezane za žanr i registar te naglašava kako je jezična komunikacija aktivnost usađena u društvo (Halliday, 1994). Žanr je matrica koja ističe jezik kao kulturalno reguliranu aktivnost koja se odvija u normaliziranom slijedu (tj. kako se pisani tekst razvija kroz etape - npr. uvod, glavni dio i zaključak u ekspozitornom tekstu). Registar na mezorazini daljnje objašnjava dinamičnu interakciju diskursnih aktivnosti i konteksta pisanoga teksta koji se izrađuje. Registar uključuje tri varijable. Polje je ono o čemu se radi u pisanom tekstu. Sadržaj se odnosi na interakciju pisanoga teksta s čitateljima. Način ili modus odnosi se na pisani kanal komunikacije. Na temelju ovih triju varijabli, pisana komunikacija prenosi tri značenja: ideacijsko značenje, interpersonalno značenje i tekstualno značenje. Te tri vrste značenja stvaraju sadržaj pisane komunikacije.

Ne ograničavajući se na prethodno rečeno, s izuzetkom strukturne točnosti, perspektiva sistemske funkcionalne lingvistike također sadrži kategorije koje dekonstruiraju tri dimenzije značenja i tako otkrivaju fenomen autentičnoga teksta na engleskom jeziku na lingvističkoj razini (Fang, 2014; Halliday, 1994; Schleppegrell, 2004). To jest, kod ideacijskoga značenja, kodovi mogu imati sudionike i procese, što može pomoći pri otkrivanju odlika akademskoga pisanja (npr. uporaba neosobnoga subjekta, nominalizacija u znanstvenim tekstovima te različit spektar uvodnih glagola od tvrditi, preko primijetiti do navesti, kada se piše u prilog ili protiv nekoga stava). Kod interpersonalnoga značenja, kodovi obuhvaćaju različite stavove (npr. autorovu emociju, prosudbu), uključenost (npr. izvor informacija) i stupnjevanje (npr. intenzitet semantičkoga opterećenja) te pokazuju kako leksički i gramatički izvori (npr. pridjevi, prilozi i modalni glagoli) otvaraju interpersonalno značenje u različitim žanrovima (npr. implicitnoj upotrebi stavova, čestoj uporabi uključenosti autora i pažljivoj uporabi stupnjevanja u znanstvenim ili akademskim esejima, kako bi se zadržala objektivnost pri iznošenju informacija). Kohezivne veze kao kodovi tekstualnoga značenja (npr. veznici, leksička ponavljanja) ilustriraju kako su dobro napisane rečenice povezane jedna s drugom, zajedno s tematskim obrascima (npr. ponavljanje na početku susjednih rečenica).

Uistinu, u brojnim je istraživanjima zabilježena važnost sistemske funkcionalne lingvistike, iako su ona uglavnom provedena u tradicionalnoj nastavi i uz udžbenike koji se koriste (npr. Accurso, Gebhard i Selden, 2016; de Oliveira i Lan, 2014). Istraživanja 
ovakvoga tipa provedena su više u kontekstima u kojima su stručnjaci iz područja sistemske funkcionalne lingvistike poučavali nastavnike i studente istoj toj vrsti lingvistike. Na primjer, Mitchel i Pessoa (2017) fokusirali su se na to kako je eksplicitna nastava sistemske funkcionalne lingvistike utjecala na uspjeh učenika u vještini pisanja. Oni su se posebno fokusirali na dva studenta na Bliskom istoku te je njihovo istraživanje primjenom kvalitativnih analiza intervjua provedenih sa studentima i njihovih pisanih uradaka pokazalo da studenti mogu uspješno napisati tekst iz područja povijesti koristeći uvodne glagole (npr. implicirati, uputiti, pokazati) kako bi poduprli ili osporili određene informacije ili kako bi prikazali vezu između opće teze i argumenata koji joj idu u prilog u procesu razrade teme. Što se tiče znanstvenoga pisanja, Accurso i sur. (2016) proveli su analizu slučaja koja je trajala 12 tjedana te su pokazali kako je učitelj u SAD-u dobio podršku od strane stručnjaka iz područja sistemske funkcionalne lingvistike kako bi pomogao studentima razviti vještinu akademskoga pisanja. Uz stručnu edukaciju, učitelj koji je sudjelovao u ovoj studiji slučaja pratio je način na koji su stručnjaci dekonstruirali tekstove, način na koji su studenti izgrađivali svoje tekstove uz pomoć nastavnika te kako su samostalno pisali i razrađivali tekst, što je kod njih uvelike razvilo znanje o karakteristikama znanstvenoga teksta i pomoglo im koristiti dostupne lingvističke izvore (npr. upotrebu znanstvenih riječi umjesto svakodnevnoga jezika, izbjegavanje subjekta u prvome licu te upotrebu veznika pri povezivanju ideja). Ova su istraživanja, bez obzira na činjenicu da je pedagoški fokus bio u tradicionalnim učionicama u kojima su osnove sistemske funkcionalne lingvistike pokrenuli i o njima poučavali vanjski stručnjaci, a ne sami nastavnici, pomogla studentima bolje razumjeti složenost procesa pisanja i uspješno napisati vlastite pisane uratke. Ovo jasno pokazuje da sistemska funkcionalna lingvistika može jako pomoći studentima u razvoju vještine pisanja akademskih tekstova tako što pažnju posvećuju jezičnim formama i izgradnji značenja u kontekstu. U ograničenom bi kontekstu tako samorazvoj nastavnika kroz primjenu online izvora u ovome okviru bio potencijalno koristan za nastavu u kojoj se obrađuje vještina pisanja. Nažalost, do sada nije provedeno ni jedno takvo istraživanje.

Sve u svemu, na temelju tri smjernice spomenute u pregledu literature u prethodnom dijelu teksta, važno je u sinergiju dovesti samodjelovanje nastavnika, online izvore te aspekt pisanja koji ovisi o žanru, kako bi se studente bolje pripremilo za uspješnu pisanu komunikaciju. Nažalost, do sada nije provedeno nijedno istraživanje o toj temi. Kako bi se taj nedostatak premostio te kako bi se ispitala područja inovacije u kurikulu pisanja u sličnim kontekstima gdje je samorazvoj nastavnika neophodan, ovo istraživanje ima za cilj pronaći odgovor na sljedeće pitanje: kako je nastavnik proveo samorazvoj u nastavi u kojoj se poučava o vještini pisanja i u kojoj se koriste online izvori temeljeni na principima sistemske funkcionalne lingvistike?

\section{Metoda istraživanja}

Cilj ove studije bio je ispitati kako nastavnici koji izvode nastavu u ograničenom kontekstu koriste online izvore. Stoga je korišten pristup analize slučaja koji omogućava 
optimalnu paradigmu za ispitivanje kontekstualnih aktivnosti na reprezentativnim sudionicima (Panton, 2005).

\section{Kontekst istraživanja: kurikul i razredno okruženje}

Istraživanje je provedeno na Odsjeku za engleski jezik na prestižnom sveučilištu u Kini. Poučavanje o vještini pisanja na sveučilištu organizira se za studente prve i druge godine dodiplomskoga studija. U kolegijima su se izmjenjivali sadržaji temeljeni na narativnim, ekspozitornim, raspravljačkim i istraživačkim tekstovima (tj. studenti su mogli sami birati istraživačko područje i napisati istraživački rad) tijekom četiri semestra unutar prve dvije akademske godine. U kolegijima u kojima se poučava o vještini pisanja, kao i u mnogim drugim kontekstima, naglasak je bio na jezičnoj točnosti (Schleppegrell, 2004; Zhang, 2017). U međuvremenu se od studenata tražilo da pročitaju materijale u obveznim udžbenicima, koji su se uglavnom sastojali od tekstova za čitanje i poneke jezične vještine (npr. kako koristiti modalne glagole). Uz to, podrška koju je Odsjek pružao nastavnicima više se sastojala od davanja općih smjernica (npr. o generičkoj strukturi pisanja), bez savjeta o tome kako bi studente uspješno mogli poučavati o vještini pisanja. Očito je ovakav institucijski scenarij, tipičan za ograničeni kontekst, od odsjeka na sveučilištu napravio pogodno mjesto za studiju slučaja o tome kako nastavnici mogu unaprijediti vlastito poučavanje o vještini pisanja.

Nadalje, Henry (pseudonim) i njegovi studenti koji pohađaju kolegij o pisanju ekspozitornih i argumentativnih tekstova odabrani su kao fokus ove analize slučaja zato što predstavljaju odgovarajući i reprezentativan uzorak (Panton, 2005). Henry ima doktorat iz područja lingvistike s američkoga fakulteta. Nakon što je diplomirao, vratio se u Kinu i poučavao u pisanju na ovome kineskom sveučilištu. Nastava je obuhvaćala pisanje i ekspozitornih i argumentativnih tekstova, iako prije toga nije nikada izvodio nastavu pisanja na fakultetskoj razini obrazovanja. Bez odgovarajuće pomoći i korisnih udžbenika, Henry se morao osloniti sam na sebe u ovome ograničenom kontekstu, kao što je slučaj i s mnogim drugim nastavnicima (Accurso i sur., 2016; Zhang, 2017). Međutim, na temelju ankete i analize znanja i prakse studenata u aktivnostima pisanja, Henry je odlučio pomoći svojim studentima uspješno razviti vještinu pisanja tako što je koristio dodatne materijale za učenje (tj. upotrebljavao je online izvore koji se temelje na sistemskoj funkcionalnoj lingvistici). Stoga je Henry tipičan nastavnik koji se oslanja sam na sebe te je relevantan primjer nastavnika za istraživanje (Beach, 2017). Nadalje, svi studenti koji su pohađali kolegij o pisanju ekspozitornih i argumentativnih tekstova bili su voljni sudjelovati u istraživanju i nije im bio problem podijeliti svoja razmišljanja o kurikulu. Prije nego što je Henry preuzeo ove kolegije, nastava se bazirala na udžbeniku i bila je ograničena na gramatiku, kao što je slučaj i u mnogim drugim kontekstima (Zhang, 2017; Schleppegrell, 2004). To je bio i rezultat ankete koju je proveo Henry. Drugim riječima, studenti nisu nikada radili na online izvorima i nisu imali iskustva s učenjem baziranom na sistemskoj funkcionalnoj lingvistici. To je dodatni razlog za odabir Henrijeve nastave za ovu studiju slučaja o samorazvoju nastavnika kroz primjenu online izvora, a s ciljem razvoja vještine pisanja kod studenata. 
Henry je sam predložio ekspozitorni tekst kao vrstu pisanoga teksta na kojemu će se raditi, a studenti su prijedlog prihvatili. U pisanju su mogli obraditi različite teme, poput znanstvenih (npr. uzroci i posljedice globalnoga zatopljenja) ili općenitih (npr. razlika između života tijekom srednje škole i tijekom studiranja na fakultetu). Svaki esej mogao je sadržavati između 500 i 600 riječi. Teme za argumentativni esej također su bile raznolike, poput rizika ili dobrobiti koje mogu imati smrtna kazna ili komercijalno surogat-majčinstvo. Broj riječi u argumentativnom eseju bio je između 1000 i 1500 riječi. Tijekom vlastitoga procesa samorazvoja, Henry je, uz tekstove iz obveznoga udžbenika, nastavu provodio uglavnom u skladu s konstruktima sistemske funkcionalne lingvistike. Odgovarajući online materijali odabrani su i korišteni u razredu ili zadani studentima za vježbu nakon nastave (vidi tablicu 1 ispod; također vidi Zhang, 2018). Opća svrha vlastitoga kurikula bila je koristiti online izvore u skladu s principima sistemske funkcionalne lingvistike kako bi se studentima pomoglo bolje razumjeti koncepte pisanja akademskih tekstova.

\section{Tablica 1.}

Kako se može vidjeti iznad u tablici 1, kurikul temeljen na samorazvoju nastavnika bio je svojevrsna spojnica sa znanjem o sistemskoj funkcionalnoj lingvistici, nastavom koja se temelji na korištenju primjera pisanih tekstova i online izvora. Tijekom nastave Henry je balansirao znanje o teoriji i praktičnoj primjeni kroz indirektan proces.

\section{Prikupljanje i analiza podataka}

Unutar paradigme analize slučaja (Panton, 2005) podatci su se uglavnom prikupljali tijekom Henryjevih kolegija u kojima je poučavao o pisanju ekspozitornih $\mathrm{i}$ argumentativnih tekstova. Svi njegovi studenti $(\mathrm{N}=38)$ pristali su sudjelovati u studiji nakon što su objavljene njihove ocjene, što je osiguralo etičnost ovoga istraživanja. Zbog toga su svi studenti bili maksimalno usredotočeni tijekom istraživanja. Podatci su obuhvaćali Henryjeve pisane refleksije o oba kolegija tijekom svakog semestra, kao i razgovore koje je vodio sa studentima tijekom i izvan nastave. Henryjeve su refleksije uglavnom sadržavale iskustva (o izazovima ili dobrim rezultatima) koja je stekao tijekom dva semestra u kojima je provodio samorazvoj, u kolegijima o pisanju ekspozitornih i argumentativnih tekstova. Što se tiče razgovora o tim kolegijima, oni su se uglavnom odvijali kada su Henry i studenti raspravljali o tome kako će najbolje strukturirati eseje i kako će najbolje razumjeti tekst kao diskurs koji je ugrađen u sam kontekst. Mora se naglasiti da je znanje na koje su se nastavnik i studenti oslanjali tijekom razgovora bilo dostupno preko online izvora koji su pokrivali holističko i adekvatno znanje o sistemskoj funkcionalnoj lingvistici, što je jedna od ključnih komponenti ove studije (Macken-Horarik, Love i Unsworth, 2011).

Kako bi se detaljno analizirala kompleksnost Henryjeva procesa samorazvoja, prikupljanje podataka obuhvatilo je refleksije studenata i intervjue, za svaki kolegij. Refleksije studenata uglavnom su uključivale njihova iskustva s kurikulom koji je izradio nastavnik. Na primjer, spominjali su vlastitu interakciju sa sadržajem online izvora i svoj put učenja. Provedeni su također i polustrukturirani intervjui kako bi se 
saznala mišljenja studenata o novom kurikulu i kako bi se razjasnile i obogatile njihove refleksije o dva kolegija. Pitanjima u intervjuu pokušalo se utvrditi kako su se prilagodili izazovima novoga kurikula te razjasniti određene aspekte koji nisu bili pokriveni ili razrađeni u refleksijama. Osim toga, prikupljeni su i zadatci koje su studenti dobili četiri eseja u kolegiju o ekspozitornom pisanju i tri eseja u kolegiju o argumentativnom pisanju (s višestrukim doradama i ispravcima nakon povratne informacije dobivene od nastavnika za svaki esej). Pisani dokumenti poslužili su kako bi se detaljno razjasnio utjecaj nastavnikova samorazvoja kroz upotrebu online izvora u nastavi.

Analiza podataka provedena je nakon induktivne analize sadržaja (Creswell, 2012). U postupku analize podataka prvo su se uspoređivali relevantni setovi podataka, koji su tada sažeti kroz konstantne usporedbe. Na primjer, pri analizi Henryjevih refleksija i usmenih razgovora, isti su puno puta pročitani i uspoređeni kako bi se otkrile glavne teme. Preliminarni kodovi u ovoj su fazi uključivali nastavnikove poteškoće, (de)motivaciju i način na koji je izgradio samopouzdanje. Za triangulaciju podataka i bolju valjanost, kao i u svrhu stvaranja detaljne slike o ovoj analizi slučaja, i ostali su podatci (npr. intervjui sa studentima, refleksije, pisani radovi i bilješke nastavnika) prošli kroz isti analitički postupak. To je pomoglo poduprijeti ili negirati analizu podataka koja su se odnosila na nastavnika. Potrebno je naglasiti da je u dva dijela analize konzultirana relevantna literatura (npr. Louws, Veen i Driel, 2017; Mushayikwa i Lubben, 2009; Zhang, 2017) i bilješke nastavnika o kolegijima, kako bi se lakše došlo do glavne teme. Na kraju su teme izdvojene iz svakog seta podataka te su dalje uspoređivane i sažimane dok se nije dobio jasan rezultat i odgovor na pitanje postavljeno u istraživanju.

\section{Rezultati istraživanja}

Usprkos činjenici da je put samorazvoja težak, Henry je pomogao studentima riješiti sve probleme koje su imali vezano uz pisanje, a koji su bili ograničeni na točnost na strukturnoj razini. Henry je sam sebe educirao o primjeni online izvora u nastavi (uključujući i one koji su bazirani na znanju o sistemskoj funkcionalnoj lingvistici i primjere tekstova) kako bi pomogao studentima dosegnuti razinu pisaca koji mogu ovladati lingvističkim resursima specifičnima za pojedini oblik pisanja da bi napisali dobar tekst. Rezultat toga bilo je i samopouzdanje koje je Henry stekao kao nastavnik koji pomaže studentima oslanjajući se na sebe kada je podrška koju mu pruža institucija u kojoj radi ograničena.

\section{Početni čimbenici koji su motivirali Henryjev samorazvoj}

Henryjev samorazvoj potaknut je njegovom odlukom da od studenata stvori autentične pisce. Ovo je jedna od njegovih refleksija:

„Moji studenti nisu znali dobro pisati. Na početku semestra proveo sam anketu $i$ inicijalni test; njihovo je znanje bilo zaista ograničeno na gramatiku... ne krivim ih... ali im zaista želim pomoći“. (ulomak iz nastavnikove refleksije).

Naglašavajući upravo isto, ovako je glasila refleksija jednog studenta: „Kada god učimo o nekoj vrsti pisanja, obično završimo tako da pišemo što god nam padne na pamet te 
obraćamo pažnju samo na strukturu i rečeničnu točnost" (ulomak iz refleksije jednog studenta). Očito je da Henryjev samorazvoj nije nastao iz vakuuma. Potaknut je vlastitim otkrićem problema u pisanim radovima studenata tijekom nastave, a dalje ga je motivirala snažna želja da pomogne studentima razviti vještinu pisanja i da krene s drugačijim načinom poučavanja. Henrijev samorazvoj uvelike je potpomognut njegovim velikim znanjem o tome što čini dobro napisani tekst, kao i samopouzdanjem koje je nastalo kroz njegova pozitivna iskustva o učenju vještine pisanja. Ovo je jedan od razgovora sa studentima:

„Znate... pisanje nije samo stvaranje gramatički točnih rečenica... ono ima posebnu društvenu svrhu... i lingvistička obilježja... I zaista se nadam da ćete u skladu s tim postupiti... No, razumijem i vašu sadašnju situaciju... i ja sam imao slična iskustva dok sam učio pisati”. (ulomak iz nastavnikovih razgovora)

Slična je još jedna od njegovih refleksija:

„Bio sam poput njih kada sam bio u Kini. No, osjetio sam snagu uspješnoga vodstva kada sam u SAD-u učio pisati tekstove. Uz sličnu nastavu... vjerujem da moji studenti isto mogu napredovati i dobro pisati". (ulomak iz nastavnikove refleksije)

Ovi ulomci pokazuju da su Henryjeva vlastita iskustva o školovanju u Kini prije odlaska na fakultet u SAD bila jednaka kao i iskustva njegovih učenika. Uz obnovljeno znanje o uspješnom pisanju, kao i uz pozitivna iskustva stečena tijekom drugačije, uspješnije nastave, Henry je bio motiviran i uvjeren da bi se njegove studente moglo naučiti boljem pisanju.

Henryjeva odlučnost da pokrene vlastiti samorazvoj također je potaknuta i pokušajima da udovolji potrebama studenata da razviju vještinu pisanja. Međutim, oni nisu znali kako to ostvariti. Ovo je Henryjeva refleksija:

„U razgovorima sa studentima saznao sam da ih ne brine znanje o gramatici, nego ih frustrira pisanje... rekli su da je jedino znanje koje imaju o pisanju to da trebaju paziti na gramatiku... nisu imali ništa drugo čime bi mogli osigurati kvalitetu pisanja... Smatram da je njihova borba s pisanjem i ovakvom kompozicijom pisanoga teksta (gdje pažnju posvećuju strukturnoj točnosti) nastala zbog nedovoljnog znanja o vještini pisanja. Stoga im moram pomoći da se u tome poprave". (ulomak iz nastavnikove refleksije)

Henryjeva briga o potrebama studenata također se mogla primijetiti i u intervjuima sa studentima:

„U stvari, radi se o tome da nisam pisao na ovakav način... Samo ne znam što sačinjava jedan dobro napisani tekst... zato sam to napravio na ovaj način... Rečeno mi je da se testovi ocjenjuju prema kriteriju točnosti... Ali svjestan sam toga da se moji pisani radovi uvelike razlikuju od primjera tekstova... Jednostavno nemam ideju... Želio bih odlično pisati”. (ulomak iz intervjua sa studentom)

Očito je da Henry nije pripremao novi kurikul na temelju vlastitih želja. Upravo suprotno, njegova se odluka temeljila na potrebama studenata za ovladavanjem vještinom 
pisanja (onih koji su željeli izazov i poboljšanje, no nisu imali dovoljno znanja za to), što je važna komponenta uspješnoga samorazvoja (Nunan i Lamb, 1996).

\section{Upotreba online izvora koji se temelje na sistemskoj funkcionalnoj lingvistici kao način ubrzanja procesa samorazvoja}

Henryjev pokušaj samorazvoja ubrzo je naišao na ograničenje u obliku sadržaja obveznih udžbenika na koje su se studenti oslanjali u razvijanju svoje vještine pisanja, jer udžbenici nisu sadržavali odgovarajuće znanje o toj vještini. To je bio poticaj Henryju da počne koristiti online izvore kao dodatak u nastavi i da pripremi učenike za uspjeh u pisanju radova. To se može vidjeti u njegovoj refleksiji:

„Udžbenik nije imao sve što sam želio iskoristiti, no čitanje je primarni kanal stjecanja znanja... Počeo sam tražiti načine... i razmišljao o online izvorima... Online izvori su praktični... i studenti im mogu lako pristupiti jer uvelike koriste računala i mobilne telefone". (ulomak iz nastavnikove refleksije)

Studenti su pokazali istu zabrinutost u svojim refleksijama:

„Uglavnom učimo o sadržaju iz udžbenika... i o ponekim jezičnim vještinama, poput veznika... ali ne znamo zašto... udžbenik ne pruža sve... možda ćemo dobiti neke materijale za čitanje... i naučiti nešto o gramatici i nekim vještinama... imam osjećaj da se sadržaj u našim udžbenicima uglavnom ponavlja... ne nudi ništa novo". (ulomak iz refleksije studenta)

Očito je da su materijali za čitanje primarni kanal za stjecanje znanja u nastavi pisanja (Zhang, 2017). Ipak, u toj je nastavi Henryjeva odluka da bude dobar nastavnik bila ograničena materijalima koji nisu pokrivali sadržaj neophodan za razvoj vještine pisanja akademskih tekstova. Usprkos tome, Henry je napravio važan korak u procesu svojega samorazvoja i odlučio je posegnuti za online izvorima jer su oni pokrivali široko znanje.

Henry se nije ograničio samo na online izvore, već ih je odlučio organizirati na način koji se temeljio na konstruktima sistemske funkcionalne lingvistike. Henry je na nastavi rekao:

„Koristio sam online izvore u nastavi Engleskog jezika kao drugoga jezika i poučavao čitanje... ne ovdje u kontekstu učenja engleskog jezika kao stranog jezika, a pogotovo ne u svrhu pisanja... no sobzirom na korisnost konstrukata sistemske funkcionalne lingvistike... smatram da ih je potrebno isprobati. No, spreman sam intervenirati u slučaju da dođe do određenih poteškoća”. (ulomak iz nastavnikovoga razgovora)

Drugim riječima, u procesu samorazvoja Henry nije nasumično koristio online izvore kako bi obogatio konceptualno znanje svojih studenata o relevantnoj temi (usporedi s Taffs i Holt, 2013). Umjesto toga, on je na temelju prijašnjih iskustava hrabro organizirao izvore prema sistemskoj funkcionalnoj lingvistici. Na taj je način obogatio znanje studenata o pisanju, iako to nikada nije isprobao u nastavi pisanja na fakultetu. 


\section{Izazovi s kojima se Henry suočio prilikom primjene online izvora temeljenih na sistemskoj funkcionalnoj lingvistici}

Međutim, upotreba online izvora u nastavi Henryju se činila teškim procesom jer su studenti imali već fosiliziran način učenja stečen tijekom dotadašnjega školovanja. To jest, studenti su navikli na nastavu u kojoj je primarni izvor udžbenik. Ovo je mišljenje jednog studenta:

„Nikada nisam imao ovakvu nastavu... nismo čitali puno online izvora... samo za stjecanje dodatnih znanja o temi o kojoj pišemo ili kako bismo provjerili gramatiku... mislim, nikada ih nismo koristili kao glavne nastavne materijale kao što to sada činimo, a ja vjerujem u čitanje udžbenika..." (ulomak iz intervjua sa studentom)

Drugim riječima, studenti nisu spremno prihvatili upotrebu online izvora jer su bili naviknuti na korištenje papirnatih udžbenika (Kwak, 2017). Zato nisu na početku dobro reagirali na suradnju s nastavnikom tijekom nastave. To se pokazalo i kasnije kada je Henry na nastavnom satu razgovarao sa studentima i provjerio kako čitaju online izvore tijekom početne faze nastave u oba kolegija.

Henry: Jeste li pročitali te izvore?

Studenti: Da, jesmo.

Henry: Dakle, kako biste definirali kontekst? I u kakvoj je on vezi s našim načinom pisanja? [Henry je studentima postavljao pitanja o materijalima.]

Studenti: Nema odgovora. [Počinju tražiti materijale na laptopima ili mobitelima.]

Henry: Rekli ste da ste ih pročitali; kako to da ne znate odgovor?

Studenti: Mislili smo da ste željeli da samo bacimo pogled na njih, ne da ih detaljno pročitamo... nikada se prije nismo susreli s tim... čitanjem teorije na nastavi pisanja. (ulomak iz razgovora nastavnika sa studentima)

Ovaj je ulomak pokazao da studenti nisu dobro reagirali na sadržaj u online izvorima, tretirali su ih kao pomoćne izvore, što je očito posljedica njihovi dotadašnjih navika učenja u tradicionalnoj nastavi, gdje je udžbenik primarni i osnovni izvor.

Henryju je zasmetala negativna reakcija studenata pa je stoga odlučio poraditi na tome. U svojoj je refleksiji zapisao: „Mislim da bi studenti trebali zapisivati svoje refleksije u dnevnik. Na taj će način online izvore čitati pažljivo i ozbiljno ih shvatiti” (ulomak iz nastavnikove refleksije). Drugim riječima, suočen s nemotiviranošću studenata da prihvate novi način korištenja materijala, Henry je bio emocionalno frustriran. Međutim, nije odustao nego je sam sebe stalno osnaživao i smišljao načine na koje će riješiti probleme koji su se javljali tijekom njegovoga samorazvoja.

Osim toga, Henryjev izazov bila je i činjenica da nije uspio prepoznati poteškoće koje su studenti imali pri razumijevanju metalingvističkih koncepata i s njihovom primjenom u pisanju, kao ni poteškoće s generičkim kriterijima. Jedan je student rekao:

„Malo mi je teško razumjeti sadržaj... treba procesuirati puno lingvističkih termina... osjećam preveliko opterećenje. Također, donekle mi je jasno o čemu se radi i što 
nastavnik govori; npr. kako koristiti uvodne glagole, no to nisam uspio sam napraviti... i na kraju sam uradak napisao na isti ovaj način". (ulomak iz refleksije studenta)

Doista, proces pisanja napredovao je puno sporije od onoga što su studenti uspjeli naučiti iz svojih pisanih radova (Stotsky, 1983). To jest, iako su studenti mogli razumjeti sadržaj online izvora, ipak ga nisu mogli primijeniti u pisanju.

Henryjev samorazvoj usporavale su i poteškoće koje su studenti imali s razumijevanjem lingvističkih zahtjeva izvan onoga što su prethodno naučili (npr. strukturna točnost), pogotovo kada se radi o razumijevanju karakteristika određenoga žanra, kao što su: neodgovarajuće iznošenje vlastitoga mišljenja u ekspozitornim tekstovima, neadekvatno znanje o tome kako uspješno osporiti protivnikove argumente u argumentativnom tekstu te nedostatak kohezije i logičnoga povezivanja u obje vrste tekstova. Dakle, studenti nisu na adekvatan način internalizirali sadržaj online izvora. Drugim riječima, ovi izazovi nastali su zbog toga što se Henry nije na vrijeme posvetio konceptualnom opterećenju studenata. On sam je rekao: „Moram smisliti način kako im pomoći... ništa ne može biti lagano..." (ulomak iz nastavnikove refleksije)

Da bi riješio probleme s kojima su studenti bili suočeni, Henry je ponovno prilagodio online izvore tako što je smanjio količinu tekstova koje je trebalo pročitati i naglasio glavna načela (Macken-Horarik i sur., 2011), a istovremeno je dao brojna objašnjenja za vrijeme i nakon nastave (na primjer, u više navrata dao je studentima povratne informacije na temelju njihovih potreba, a vodio je i bilješke o radu). Odlučio je da će im ponovno objasniti sadržaj materijala za čitanje na temelju onoga što je saznao iz razgovora s njima (bilješke o radu). To je dovelo do promjene scenarija. Kako je jedan student iz kolegija o ekspozitornom pisanju rekao: „Kroz stalnu i ponovljenu komunikaciju, u obliku povratne informacije i razgovora za vrijeme i izvan nastave, sada mogu bolje razumjeti vrijednost online izvora i njihovu vezu s pisanjem." (ulomak iz intervjua sa studentom)

Slično tome, drugi student, koji je pohađao kolegij o argumentativnom pisanju, također je rekao:

„Imam osjećaj da je količina materijala koje moramo pročitati znanstveno organizirana... a nastavnik nam je dao i više prilike za vježbu na nastavi i ponudio dodatnu pomoć nakon nastave... to mi je pomoglo da se bolje prilagodim kurikulu”. (ulomak iz intervjua sa studentom)

Očito su poteškoće koje su se pojavljivale na putu Henryjeva samorazvoja bile sporadične. U svojim reakcijama na njih je Henry uvijek nalazio način kako osnažiti samoga sebe i potražio je rješenja kako bi pomogao studentima da se odmaknu od dotadašnjih stilova učenja. $U$ tome mu je uvelike pomagalo samopouzdanje koje je izgradio tijekom cijeloga procesa. Naveo je: „Nisam cijelo vrijeme osjećao uspjeh... no osjećam da studenti napreduju, iako ne onako glatko kao što sam očekivao... sporo napreduju, još se razvijaju... To mi je pomoglo da nastavim provoditi svoj kurikul u nastavi i istovremeno me motiviralo da potražim strategije prilagodbe studenata kurikulu koji sam uveo." (ulomak iz nastavnikove refleksije) 


\section{Henryjeva konceptualizacija nastavnikove uloge i izgradnja vlastitoga samopouzdanja tijekom primjene online izvora temeljenih na sistemskoj funkcionalnoj lingvistici kao rezultat napretka studenata}

Na sredini svakoga kolegija Henry je izgradio samopouzdanje jer su studenti kontinuirano napredovali i prevladavali probleme nastale zbog prijašnjega načina učenja. Henryjeve intervencije (npr. povratna informacija) bile su minimalne, a uglavnom su uključivale provjeru izvora o određenom žanru pisanja. Uistinu, od početka drugog kruga revidiranja drugoga pisanog uratka u kolegiju o pisanju ekspozitornih tekstova i drugoga kruga revidiranja prvoga pisanog uratka u kolegiju o pisanju argumentativnih tekstova, činilo se da studenti aktivnije reagiraju na ranije napisanu povratnu informaciju o npr., upotrebi veznika, prijelazu na ostatak teksta nakon uvoda te balansiranju procjenjivačkih stavova u pisanim radovima (vidi tablicu 3 ispod). Drugim riječima, za razliku od pasivnih preuređivanja eseja u prijašnjoj nastavi, počeli su pokazivati aktivno revidiranje vlastitih pisanih radova na temelju pisane povratne informacije nastavnika, što je bio rezultat većega znanja koje su stekli.

Tablica 2.

Drugim riječima, Henryjev samorazvoj dobro je pripremio studente za prijelaz u status autentičnih autora teksta, a koji obuhvaća puno više od rečenične točnosti. Studenti su konačno mogli zadovoljiti kriterije autentičnoga pisanja zbog integrirane upotrebe online izvora i smjernica temeljenih na sistemskoj funkcionalnoj lingvistici. Toga je mišljenja bio i jedan student:

„Usprkos teškom procesu učenja, osjetio sam se sposobnim nastaviti rad jer smo prolazili kroz postupan proces... znanje o registru i prebacivanje izmedu tri metaznačenja $i$ relevantnih lingvističkih izvora,... to je bio dodatak mojem znanju... pomoglo mi je bolje razumjeti perspektivu žanra kada se radi o pisanju argumentativnoga ili expozitornoga teksta..." (ulomak iz intervjua sa studentom)

Henry je uz samopouzdanje obnovio i vlastito znanje o tome kako koristiti online izvore da bi se premostio jaz između prethodnoga načina na koji su studenti učili i stvarnih zahtjeva. Ovo je zapisano u Henryjevoj refleksiji:

„Studenti sada više ne obraćaju pažnju samo na gramatiku, nego su izgradili cjelovitu sliku o tome da je pisanje aktivnost ugrađena u kontekst... sve se sada isplatilo... To me je još više uvjerilo da se dobrim nastavnikom može postati kroz vlastiti rad i inicijativu... Također me još više motiviralo da krenem istim putem u nastavi ostalih kolegija koje budem držao". (ulomak iz nastavnikove refleksije)

„Nastavnik se ne bi trebao oslanjati samo na vanjske izvore... ono što nastavnik treba raditi jest koristiti dostupne izvore i pomoći studentima... K tome, i oni trebaju biti dobro pripremljeni za izazove na koje će putem naići”. (ulomak iz nastavnikove refleksije) 
Henry je tijekom svojega zahtjevnog putovanja u nastavi o pisanju ekspozitornih i argumentativnih tekstova stekao nova saznanja o tome kako biti stručan nastavnik. U takvom ograničenom nastavnom kontekstu od velike je važnosti moći se osloniti na samoga sebe, prije svega zbog potreba studenata. Drugim riječima, Henry je stekao holističku perspektivu o tome kakav stručan nastavnik koji poučava o pisanju treba biti, a sve kroz dinamična iskustva stečena u dva kolegija u kojima nije imao adekvatnu pomoć institucije u kojoj je radio (što je uključivalo i nedostatak literature o stručnom usavršavanju).

Henryjeva rekonceptualizacija nastavnikove uloge bila je posebno uočljiva u samopouzdanju koje je pokazivao kada je studentima objašnjavao proces pisanja u tri dimenzije kroz primjenu online izvora temeljenih na sistemskoj funkcionalnoj lingvistici i kroz poštivanje generičkih kriterija. Ovo je napisao u refleksiji:

„On [samorazvoj] ovisi o tome kakve posebne alate moramo koristiti da bismo razvijali sami sebe... ne možemo biti slijepi... i moramo razmišljati o potrebama lokalnih škola i prilagoditi im se. ... sistemska funkcionalna lingvistika tu može biti od velike pomoći... a njezina korisnost može se povećavati mnoštvom online izvora". (ulomak iz nastavnikove refleksije)

Njegovo samopouzdanje u korištenju online izvora temeljenih na sistemskoj funkcionalnoj lingvistici imalo je posebno uporište na sljedećim dimenzijama:

„Poučavanje studenata kako pročitati ideacijski konstrukt kroz online izvore može im ponuditi odabir odgovarajućih riječi i regulirati logičke veze... kao što je adekvatna upotreba glagola za isticanje drugačijega semantičkog opterećenja... svi ti glagoli nisu bilo kakvi gramatički prihvatlivi glagoli, nego se dijele prema određenoj vrsti teksta". (ulomak iz nastavnikove refleksije)

„Interpersonalni konstrukt i relevantni online izvori naučili su studente da izbjegavaju riječi kojima iznose vlastite stavove kada podupiru određene ideje... i mogli smo navesti izvor informacija kako bismo pokazali objektivnost u tekstu. I moramo također uvesti promjene u različite žanrove... tvrdnja u argumentativnom eseju ne može izricati eksplicitan stav. Nikakvo znanje nije fiksno". (ulomak iz nastavnikove refleksije)

„Spajanje tekstualnoga značenja s online izvorima pomoglo je studentima koji su se prije toga fokusirali na sintaktičku točnost rečenica, bez znanja o koheziji... kohezivne veze pomažu mi provjeriti tok misli studenata u pisanom uratku, kada navode dokaze iz raznih istraživanja ili na drugim mjestima u pisanom uratku". (ulomak iz nastavnikove refleksije)

Očigledno je upotreba online izvora temeljenih na sistemskoj funkcionalnoj lingvistici studentima pomogla ostvariti napredak prema uspješnoj komunikaciji. Napredak je tada utjecao na Henryjevo samopouzdanje i pomogao mu postati profesorom koji se može osloniti na sebe sama te se fokusirati na mikrorazinu poučavanja u vještini pisanja kroz primjenu online izvora. 


\section{Rasprava i implikacije}

Ova studija slučaja polučila je nekoliko rezultata. Prije svega, fokusirajući se na Henryjev samorazvoj, posebno na način kojim je u kurikul unio inovacije, studija je pokazala dinamičan proces upotrebe online izvora kako bi nastavnik sam unaprijedio vlastito znanje i pomogao studentima pri razvoju vještine pisanja. Tijekom procesa samorazvoja Henry je prebrodio brojne kontekstualne čimbenike koji su mu uzburkali emocije. $\mathrm{Na}$ primjer, njegov trud naišao je na brojne prepreke jer su studenti bili spori u radu, a opirali su se i novom kurikulu. Henry sam nije uspio pravovremeno prepoznati kontekst učenja na nastavi (npr. kako je način na koji studenti uče ograničen njihovim kognitivnim opterećenjem). Ipak, Henryjev ukupan samorazvoj malo je na kraju razvodnjen zbog toga što je stalno morao studentima objašnjavati vezu između online izvora, udžbenika i pisane komunikacije, kako bi im pomogao da to što bolje razumiju. Na kraju su studenti, kao rezultat njegovih nastojanja, mogli napisati tekst s određenom generičkom svrhom, umjesto da samo pišu gramatički točne rečenice. To je Henryju pomoglo izgraditi samopouzdanje i samodostatnost u ograničenom kontekstu poučavanja. U tom smislu ova studija ukazuje na dobrobit samorazvoja u ograničenim kontekstima te posebno naglašava moć samorazvoja u nastavi pisanja i ondje gdje postoji velika potreba za učinkovitim poučavanjem i pripremanjem studenata za pisanu komunikaciju tijekom akademskoga obrazovanja (Mushayikwa i Lubben, 2009; Nunan i Lamb, 1996). Osim toga, ova studija povezuje i nekoliko već provedenih studija (Mushayikwa i Lubben, 2009) u kojima se izrazito naglašava upotreba online izvora u poučavanju vještine pisanja (usporedi s Louws i sur., 2017). U tom smislu ovaj rezultat nadovezuje se na rezultate ranijih istraživanja o samorazvoju u tradicionalnoj nastavi, u kojima se ispitivao, npr. nastavnikov izbor dodatnih udžbenika (usporedi sa Zhang, 2017). Najvažnije je to što je, fokusiranjem na Henryjev put samorazvoja, studija empirijski pokazala dinamiku, poteškoće i dobrobit samorazvoja uz pomoć tehnologije, što do sada nije dovoljno zabilježeno u postojećoj literaturi (Mushayikwa i Lubben, 2009). To može pomoći u budućim inovacijama kurikula, kada se nastavnici moraju osloniti sami na sebe i pomoći studentima uspješno razviti vještinu pisanja.

Kao drugo, fokusiranjem na sistemsku funkcionalnu lingvistiku kao podlogu za samorazvoj nastavnika, ova je studija pokazala napredak studenata u razvoju vještine pisanja na lingvističkoj razini. To jest, u ovom je procesu, uz eksplicitnu upotrebu online izvora temeljenih na sistemskoj funkcionalnoj lingvistici u poučavanju vještine pisanja, studija pokazala da su studenti stekli znanje o tome kako doraditi svoju originalnu konceptualizaciju pisanja i kako dobro reproducirati tekst, iako taj proces nije bio jednostavan. Na primjer, usprkos teškom putu učenja, studenti su mogli primijeniti stečeno znanje o sistemskoj funkcionalnoj lingvistici i stručno napisati tekst koji nadilazi granice gramatičke točnosti, a sve zahvaljujući provedbi Henryjeva kurikula temeljenoga na samorazvoju. Zbog toga se ova studija nastavlja na tradicionalna istraživanja u kojima su nastavnici imali pomoć stručnjaka u primjeni sistemske funkcionalne lingvistike, što je išlo u prilog razvoju vještine pisanja kod njihovih studenata (usporedi s Accurso 
i sur., 2016; Mitchell i Pessoa, 2017; de Oliveira i Lan, 2014). Međutim, isticanjem samoinicijativnoga angažmana nastavnika u primjeni sistemske funkcionalne lingvistike kao alata i korištenja online izvora, ova studija daje svoj doprinos postojećoj literaturi o pedagogiji pisanja, tako što naglašava sistemsku funkcionalnu lingvistiku kao učinkovit alat za upotrebu online izvora kao materijala za učenje i poučavanje. Drugim riječima, ova studija također daje svoj doprinos popisu alata za samorazvoj nastavnika koji poučavaju u ograničenim kontekstima i bolje odgovara mišljenju Taffsa i Holta (2013) da „se odluke o nastavnom dizajnu koji uključuje primjenu e-izvora moraju prvo temeljiti na svrsi i pedagoškom aspektu, a ne samo na dostupnim tehnologijama." (str. 500)

Implikacije ove studije uključuju nekoliko aspekata. Kao prvo, iako je samorazvoj ključan za profesionalni razvoj nastavnika i za akademski uspjeh studenata, i nastavnici i studenti mogu osjetiti emocionalne uspone i padove tijekom toga procesa. To znači da se čak i u ograničenim kontekstima, gdje se vanjska podrška ne može pružiti na službeni ili odgovarajući način, može pokrenuti suradnja s kolegama (npr. stručnjacima za lingvistiku ili online tehnologiju) koji bi pomogli nastavnicima u samorazvoju i olakšali im taj proces. Osim toga, samorazvoju također može biti prepreka neprepoznavanje potreba studenata. Drugim riječima, trebale bi se provoditi edukacije nastavnika koji već rade u nastavi, kako bi ih se poučilo refleksivnoj praksi, što bi im pomoglo pokrenuti uspješan proces samorazvoja. Još važnije, s obzirom na to da je pisana komunikacija kompleksan pojam, a sistemska funkcionalna lingvistika je pogodna za objašnjenje pisanoga diskursa, bilo bi korisno o njoj educirati nastavnike stranih jezika. Na taj bi se način olakšao njihov budući samorazvoj, a studenti pripremili za uspješnu pisanu komunikaciju.

\section{Zaključak}

Unutar paradigme studije slučaja, projekt ima dva važna rezultata koji objašnjavaju kurikul koji se temelji na upotrebi online izvora u poučavanju o vještini pisanja. Prvo, studija je pokazala da je u ograničenom kontekstu samorazvoj nastavnika od ključne važnosti za kvalitetu nastave pisanja. Bez vanjske podrške, nastavnici mogu samoinicijativno započeti proces u kojemu će otkriti kakve probleme studenti imaju pri pisanju tekstova, kakav je njihov akademski napredak, pronaći rješenja te kroz postupak pokušaja i pogreške razviti njihove vještine pisane komunikacije. Još važnije, studija je pokazala i da je sinergija sistemske funkcionalne lingvistike i online izvora korisna za ubrzanje samorazvoja nastavnika i za bolji razvoj vještine pisanja kod studenata. Uz višeslojne konstrukte i naglasak na autentičnoj komunikaciji, ovi su rezultati korisni i mogu pomoći nastavnicima u pronalasku odgovarajućih rješenja za dileme koje njihovi studenti imaju vezano uz pisanje te kada su skloniji tome da se usredotoče na rečeničnu točnost nego na autentičan diskurs.

Ipak, ograničenja ove studije ne mogu se zanemariti. Kako se radi o studiji slučaja, rezultatima se treba pristupiti s oprezom. Također, mogu se uzeti u obzir i drugi čimbenici kada se promiče samorazvoj - npr. situacija kada je nastavniku dopušteno da sam izradi vlastiti kurikul. Osim toga, nastavnik u ovoj studiji slučaja imao je znanje o lingvistici, 
što mu je u određenoj mjeri pomoglo u procesu samorazvoja. Buduća bi se istraživanja mogla fokusirati na nastavnike koji nemaju lingvističko znanje i ispitati njihov put samorazvoja kroz primjenu online izvora i njihovu izgradnju profesionalnoga identiteta.

\section{Zahvala}

Projekt je financirala Nacionalna zaklada za društvene znanosti Kine (17CYY019). 